\title{
Native species exploited by marine aquarium trade in Brazil
}

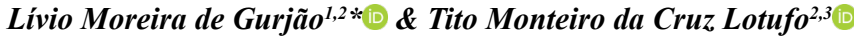

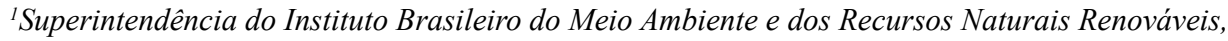 \\ Fortaleza, CE, Brasil \\ ${ }^{2}$ Universidade Federal do Ceará, Instituto de Ciências do Mar, Programa de Pós-Graduação em Ciências \\ Marinhas Tropicais, Fortaleza, CE, Brasil \\ ${ }^{3}$ Universidade de São Paulo, Instituto Oceanográfico, Departamento de Oceanografia Biológica, \\ São Paulo, SP, Brasil \\ *Corresponding author: Livio Moreira de Gurjão, e-mail: livio.gurjao@gmail.com
}

GURJÃO, L. M., LOTUFO, T. M. C. Native species exploited by marine aquarium trade in Brazil. Biota Neotropica. 18(3): e20170387. http://dx.doi.org/10.1590/1676-0611-BN-2017-0387

\begin{abstract}
Brazil has an important role in marine ornamental trade, exploiting native species for both international and domestic market. A few works have previously assessed wild species exploited by the Brazilian marine aquarium industry and most of them focused solely on fish. Hence, the present paper intends to address an information gap regarding the species currently traded in the country, as well as concerning their conservation statuses. Thus, different sources of information were investigated and each species was categorized in accordance with existing lists of threatened species. A wide variety of native species was identified in Brazilian marine aquarium trade, including not only fish but also invertebrates, seaweeds and macrophytes. Some of these species were legally protected, but are still commerced anyway. Such illegal exploitation of native species causes increasing concerns about the sustainability of the activity. Therefore, in order to reduce environmental impacts caused by marine ornamental trade, Brazilian authorities should encourage the implementation of eco-fees, the purchase of eco-labeled aquarium products, the development of sustainable ornamental aquaculture and ecosystem-based management initiatives.

Keywords: Marine aquarium fish, marine invertebrates, seaweeds, marine macrophytes, illegal trade, threatened species.
\end{abstract}

\section{Espécies nativas explotadas pela aquariofilia marinha no Brasil}

Resumo: O Brasil possui um papel importante no comércio de ornamentais marinhos, utilizando espécies tanto para exportação como para o mercado interno. Poucos trabalhos anteriores descreveram as espécies nativas utilizadas pela indústria brasileira de aquarismo marinho, e a maioria deles era focada exclusivamente no uso de peixes. Assim, o presente trabalho almeja preencher a falta de informação em relação às espécies atualmente exploradas no país, bem como relativas às suas categorias de conservação. Dessa forma, diferentes fontes de informação foram investigadas e cada espécie foi categorizada de acordo com as listas de espécies ameaçadas existentes. Uma grande variedade de espécies foi identificada no comércio do aquarismo marinho brasileiro, o que inclui não somente peixes, mas também invertebrados, macroalgas e macrófitas. Algumas dessas espécies não poderiam ser exploradas, mas mesmo assim seguem sendo comercializadas. Essa utilização ilegal de espécies nativas provoca preocupações frequentes acerca da sustentabilidade dessa atividade. Desse modo, para reduzir os impactos ambientais causados pelo aquarismo marinho, as autoridades brasileiras deveriam incentivar a implementação de taxas-ecológicas, a aquisição de produtos de aquário com selos ecológicos, o desenvolvimento sustentável da aquacultura ornamental e iniciativas de manejo baseadas no ecossistema.

Palavras-chave: Peixes de aquário marinho, invertebrados marinhos, macroalgas marinhas, macrófitas marinhas, comércio ilegal, espécies ameaçadas. 


\section{Introduction}

Marine ornamental trade is a global multi-million dollar industry ( $\sim$ US\$200-300 million annually), involving the collection of more than 50 million coral reef animals (e.g. fish, corals and a wide variety of invertebrate species) to supply aquaria kept by 2 million hobbyists worldwide (Wabnitz et al. 2003, Rhyne et al. 2012a). It is estimated that the activity targets over 1,800 reef fish species from 125 families, over 150 species of stony corals and hundreds of species of non-coral invertebrates (Rhyne et al. 2012b, Rhyne et al. 2014, Leal et al. 2015).

Since both fish and invertebrates began to be exploited together in the mid $1980 \mathrm{~s}$, consumers gradually shifted their preference from fish-only tanks to miniature reef ecosystems (Bruckner 2005, Rhyne et al. 2009, Rhyne et al. 2012a, Murray \& Watson 2014) and collectors for the aquarium trade started to act as a peculiar and unprecedented type of generalist predators, targeting both abundant and rare species, including those with critical ecological roles on the reefs (Rhyne et al. 2012b). Unlike freshwater ornamental commerce, where about $90 \%$ of fish species are produced in captivity, the great majority of marine tank species is wild-caught and, thus, elicited controversies regarding the sustainability of the activity (Wabnitz et al. 2003, Olivotto et al. 2011, Rhyne et al. 2014), as over-harvesting is among the most serious causes of coral reef degradation worldwide (Bellwood et al. 2004, Rhyne et al. 2014).

Brazil supplies significant quantities of the global marine ornamental market (Wood 2001, Bruckner 2005, Rhyne et al. 2012b) and, as in the other exporting countries, most of the exported organisms are wild-harvested, which also raised concerns about the development of this activity (Gasparini et al. 2005, Nottingham et al. 2005a).

Despite the importance of a wide variety of native organisms for both international and domestic aquarium trade, the great majority of studies available in Brazil focused on the exploitation of marine fish only (Nottingham et al. 2000, Monteiro-Neto et al. 2003, Nottingham et al. 2005a, Nottingham et al. 2005b, Ibama 2008a, Sampaio \& Nottingham 2008, Sampaio \& Ostrensky, 2013), and very few included the ornamental use of other marine organisms (Gasparini et al. 2005, Ibama 2008b). Thus, the goal of the present study was to list the Brazilian native species used in marine aquarium trade, providing information about their usage and conservation statuses.

\section{Material and Methods}

First, three different lists of species were compiled: (1) fish, (2) invertebrates and (3) seaweeds and aquatic macrophytes.

These inventories were based on the following sources of information: (1) scientific literature, (2) governmental lists, (3) demands of exportation sent to the Brazilian Institute of the Environment and Renewable Natural Resources (Ibama, Instituto Brasileiro do Meio Ambiente e dos Recursos Naturais Renováveis), (4) author's personal observation, (5) visits to online marine aquarium discussion forums (e.g. http://www.ipaq.org.br, http://www.reefcorner.org, http:// www.reefforum.net and http://www.reefdeep.org/), (6) Brazilian pet shops websites, and (7) auction websites (http://www.mercadolivre. com.br, http://www.olx.com.br and http://www.bomnegocio.com). Searches on the literature and forums were not structured with specific keywords in order to keep it flexible enough to maximize the detection of relevant information. For instance, for pet-shops websites were used the combinations: "lojas de aquário marinho Brasil", "aquario marinho loja", "peixes ornamentais marinhos Brasil", "venda de peixes ornamentais marinhos" and "lojas de peixes marinhos Brasil".

The natural distribution for each species in Brazil was obtained using information from the following databases: http://www.fishbase. org, http://www.iucnredlist.org, http://www.marinespecies.org, as well as specific literature cited in the results section. Official data from Brazilian authorities (IN IBAMA 202/2008 and decree MMA $445 / 2014$ ) and demands from export companies was also analyzed. Additionally, personal observations while visiting aquarium shops in Fortaleza (Ceará state - CE), supervision of ornamental fish unloading in Fortim (CE), visits to ornamental organisms exporting companies in Fortaleza and an aquaculture farm in Aquiraz (CE) were also used to complement the species lists.

Only species with explicit usage in aquaria were included in the inventories. Therefore, organisms exploited exclusively as handcrafts, souvenirs, curio, or for either medical or magic-religious purposes were not analyzed. The exploitation of species was analyzed concerning specific norms and the threatening statuses of each species were determined based on the Brazilian lists of threatened species and the International Union for Conservation of Nature - IUCN red list of threatened species.

\section{Results}

Exploitation allowance for all species inventoried was analyzed regarding the norms that regulate their usage in Brazil: IN Ibama 202/08 for marine fish and IN MMA 89/06 for seaweeds. As there is a paucity of specific norms for the exploitation of marine invertebrates and marine macrophytes, the only applicable rule is federal law 9,605/98.

Concerning the species' conservation statuses, fish and invertebrate were evaluated according to their classification in the Brazilian list of threatened fish and aquatic invertebrate species (decree MMA 445/14) and the IUCN red list (version 2016-3), both using the same threatening categories: (NE) Not Evaluated, (DD) Data Deficient, (LC) Least Concern, (NT) Near Threatened, (VU) Vulnerable, (EN) Endangered, (CR) Critically Endangered, (EW) Extinct in the Wild or (EX) Extinct. For the analysis of the conservation statuses of seaweeds and aquatic macrophytes, it was used the Brazilian list of threatened flora species (decree MMA 443/14) and again the IUCN red list criteria (version 2016-3).

More than 200 bone and cartilaginous fish species were identified based on 24 different sources of information (Table 1). From this total, only 136 species can be legally exploited according to IN Ibama 202/08. However, according to decree MMA 445/14, some species whose collection is not allowed by IN Ibama 202/08 may be exploited by means of specific authorizations (species categorized as VU) and others can be harvested for scientific research or conservation purposes only (species classified as EN or CR). In addition, Table 1 reports the occurrence of five fish species endemic to Brazilian oceanic islands, two new species from different genera and four updated scientific names for species reported under other synonyms in previous works.

Invertebrates were classified into seven groups: mollusks, cnidarians, crustaceans, echinoderms, polychaetes, ascidians and sponges. The first four were the most representative regarding the number of species, and some of them are included in both the Brazilian list of threatened fish and aquatic invertebrate species and the IUCN red list (Table 2). 
Brazilian species in marine aquarium trade

Table 1. Marine fish species traded in Brazil for aquarium purposes and their conservation status

\begin{tabular}{|c|c|c|c|c|}
\hline Species & $\begin{array}{l}\text { Harvesting in } \\
\text { accordance with } \\
\text { IN 202/08 } \\
\end{array}$ & $\begin{array}{l}\text { Brazilian list of } \\
\text { threatened fish species } \\
\text { (Decree MMA 445/14) }\end{array}$ & $\begin{array}{l}\text { IUCN red list } \\
\text { of threatened } \\
\text { species } \\
\end{array}$ & Observation \\
\hline \multicolumn{5}{|l|}{ Osteichthyes } \\
\hline Abudefduf saxatilis s;4; $; 11 ; 18 ; 19 ; 22 ; 21 ; 23 ; 24$ & Allowed & NE & $\mathrm{LC}$ & - \\
\hline Acanthostracion polygonius $^{4 ; 9 ; 11 ; 18 ; 19}$ & Allowed & $\mathrm{NE}$ & $\mathrm{LC}$ & - \\
\hline Acanthostracion quadricornis ${ }^{1 ; 4 ; 7 ; 9 ; 11 ; 18 ; 19 ; 24}$ & Allowed & $\mathrm{NE}$ & $\mathrm{LC}$ & - \\
\hline Acanthurus chirurgus ${ }^{1 ; 2 ; 7 ; 9 ; 11 ; 18 ; 19 ; 22 ; 24}$ & Allowed & $\mathrm{NE}$ & $\mathrm{LC}$ & - \\
\hline Acanthurus coeruleus ${ }^{1 ; 2 ; 4 ; 6 ; 9 ; 11 ; 18 ; 19 ; 22 ; 23 ; 24}$ & Allowed & NE & $\mathrm{LC}$ & - \\
\hline Achirus lineatus ${ }^{11 ; 18 ; 19}$ & Allowed & $\mathrm{NE}$ & $\mathrm{LC}$ & - \\
\hline Alphestes afer ${ }^{9 ; 11 ; 18 ; 19}$ & Allowed & $\mathrm{DD}$ & $\mathrm{LC}$ & - \\
\hline Anisotremus moricandi $i^{4 ; 9 ; 21}$ & Prohibited & NE & $\mathrm{LC}$ & - \\
\hline Anisotremus surinamensis ${ }^{9 ; 11 ; 18 ; 19}$ & Allowed & DD & $\mathrm{NE}$ & - \\
\hline Anisotremus virginicus ${ }^{1 ; 4 ; 6 ; 8 ; 9 ; 11 ; 18 ; 19 ; 22 ; 23}$ & Allowed & $\mathrm{NE}$ & $\mathrm{LC}$ & - \\
\hline Antennarius multiocellatus ${ }^{1 ; 6 ; 18 ; 21}$ & Prohibited & DD & $\mathrm{LC}$ & - \\
\hline Antennarius striatus ${ }^{4 ; 11 ; 18 ; 19 ; 21}$ & Allowed & DD & $\mathrm{LC}$ & - \\
\hline Apogon americanus ${ }^{11 ; 18 ; 19 ; 21 ; 22 ; 24}$ & Allowed & NE & $\mathrm{NE}$ & - \\
\hline Apogon maculatus $^{1}$ & Prohibited & $\mathrm{NE}$ & $\mathrm{LC}$ & - \\
\hline Apogon planifrons $^{4 ; 11 ; 21}$ & Prohibited & $\mathrm{NE}$ & $\mathrm{LC}$ & - \\
\hline Apogon pseudomaculatus ${ }^{1 ; 1 ; 18 ; 19 ; 21}$ & Allowed & $\mathrm{NE}$ & $\mathrm{LC}$ & - \\
\hline Bodianus insularis ${ }^{12 ; 18 ; 20}$ & Prohibited & $\mathrm{NE}$ & $\mathrm{LC}$ & EI \\
\hline Bodianus pulchellus ${ }^{1 ; 6 ; 9 ; 11 ; 18 ; 19 ; 21 ; 22 ; 23 ; 24}$ & Allowed & $\mathrm{NE}$ & $\mathrm{LC}$ & - \\
\hline 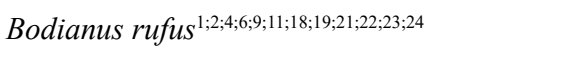 & Allowed & $\mathrm{NE}$ & $\mathrm{LC}$ & - \\
\hline Bothus lunatus ${ }^{4 ; 9 ; 11 ; 18 ; 19}$ & Allowed & $\mathrm{NE}$ & $\mathrm{LC}$ & - \\
\hline Bothus ocellatus ${ }^{7 ; 9 ; 11 ; 18 ; 19}$ & Allowed & $\mathrm{NE}$ & $\mathrm{LC}$ & - \\
\hline Calamus spp..$^{9}$ & - & - & - & - \\
\hline Calamus pennatula ${ }^{11 ; 18 ; 19}$ & Allowed & $\mathrm{NE}$ & $\mathrm{LC}$ & - \\
\hline Cantherhines macrocerus ${ }^{1 ; 4 ; 11 ; 18 ; 19 ; 21 ; 23 ; 24}$ & Allowed & $\mathrm{NE}$ & $\mathrm{LC}$ & - \\
\hline Cantherhines pullus s; $149 ; 11 ; 18 ; 19 ; 21$ & Allowed & $\mathrm{NE}$ & $\mathrm{LC}$ & - \\
\hline Canthigaster figueiredoi $i^{1 ; 4 ; 9 ; 11 ; 18 ; 1 ; ; 21 ; 24}$ & Allowed & $\mathrm{NE}$ & $\mathrm{LC}$ & - \\
\hline Carangoides crysos $^{9}$ & Prohibited & NE & $\mathrm{LC}$ & - \\
\hline Caranx latus ${ }^{9}$ & Prohibited & $\mathrm{NE}$ & $\mathrm{LC}$ & - \\
\hline Caranx lugubris ${ }^{9}$ & Prohibited & $\mathrm{NE}$ & $\mathrm{LC}$ & - \\
\hline Centropyge aurantonotus ${ }^{1 ; 2 ; 4 ; 6 ; 7 ; 9 ; 11 ; 18 ; 19 ; 21 ; 22 ; 23 ; 24}$ & Allowed & DD & $\mathrm{LC}$ & - \\
\hline Cephalopholis fulva $a^{1 ; 9 ; 18 ; 19}$ & Prohibited & $\mathrm{NE}$ & $\mathrm{LC}$ & - \\
\hline Chaetodipterus faber $r^{1 ; 6 ; 11 ; 18 ; 19 ; 23}$ & Allowed & NE & $\mathrm{LC}$ & - \\
\hline Chaetodon ocellatus ${ }^{1 ; 2 ; 4 ; 6 ; 7 ; 11 ; 18 ; 19 ; 21 ; 22 ; 23 ; 24}$ & Allowed & DD & $\mathrm{LC}$ & - \\
\hline
\end{tabular}


Gurjão, L.M. et al.

Continued Table 1.

\begin{tabular}{|c|c|c|c|c|}
\hline Species & $\begin{array}{c}\text { Harvesting in } \\
\text { accordance with } \\
\text { IN 202/08 } \\
\end{array}$ & $\begin{array}{c}\text { Brazilian list of } \\
\text { threatened fish species } \\
\text { (Decree MMA 445/14) }\end{array}$ & $\begin{array}{c}\text { IUCN red list } \\
\text { of threatened } \\
\text { species } \\
\end{array}$ & Observation \\
\hline Chaetodon sedentarius ${ }^{1 ; 2 ; 4 ; 6 ; 9 ; 11 ; 18 ; 19 ; 21 ; 22}$ & Allowed & $\mathrm{NE}$ & $\mathrm{LC}$ & - \\
\hline Chaetodon striatus ${ }^{1 ; 2 ; 4 ; 6 ; 7 ; 9 ; 11 ; 18 ; 19 ; 21 ; 22 ; 23 ; 24}$ & Allowed & $\mathrm{NE}$ & $\mathrm{LC}$ & - \\
\hline Chilomycterus antennatus $^{11 ; 18 ; 19 ; 23}$ & Allowed & $\mathrm{NE}$ & $\mathrm{LC}$ & - \\
\hline Chilomycterus antillarum ${ }^{1 ; 11 ; 18 ; 19}$ & Allowed & $\mathrm{NE}$ & $\mathrm{LC}$ & - \\
\hline Choranthias salmopunctatus ${ }^{13 ; 18 ; 20}$ & Prohibited & VU & $\mathrm{LC}$ & EI, DN* \\
\hline Chromis flavicauda ${ }^{1 ; 4 ; ; ; 21}$ & Prohibited & NE & DD & - \\
\hline Chromis jubauna $a^{4 ; 9 ; 21}$ & Prohibited & $\mathrm{NE}$ & $\mathrm{NE}$ & - \\
\hline Chromis multilineata ${ }^{1 ; 4 ; 9 ; 11 ; 18 ; 19 ; 21}$ & Allowed & $\mathrm{NE}$ & $\mathrm{LC}$ & - \\
\hline Coryphopterus glaucofraenum ${ }^{11 ; 18 ; 19 ; 23}$ & Allowed & $\mathrm{NE}$ & $\mathrm{LC}$ & - \\
\hline Cosmocampus albirostris ${ }^{10 ; 11 ; 18 ; 19 ; 23}$ & Allowed & $\mathrm{NE}$ & $\mathrm{LC}$ & - \\
\hline Cryptotomus roseus ${ }^{9}$ & Prohibited & $\mathrm{NE}$ & $\mathrm{LC}$ & - \\
\hline Cychlichthys spinosus s:11;18;19;21 $^{2}$ & Allowed & $\mathrm{NE}$ & NE & - \\
\hline Dactylopterus volitans ${ }^{1 ; 2 ; 6 ; 9 ; 11 ; 18 ; 19}$ & Allowed & $\mathrm{NE}$ & $\mathrm{LC}$ & - \\
\hline Dermatolepis inermis ${ }^{9}$ & Prohibited & NE & NT & - \\
\hline Diodon holacanthus ${ }^{4 ; 11 ; 18 ; 19}$ & Allowed & NE & $\mathrm{LC}$ & - \\
\hline Diodon hystrix ${ }^{1 ; 6 ; 9 ; 11 ; 18 ; 19 ; 24}$ & Allowed & $\mathrm{NE}$ & $\mathrm{LC}$ & - \\
\hline Diplectrum formosum ${ }^{11 ; 18 ; 19}$ & Allowed & $\mathrm{NE}$ & $\mathrm{LC}$ & - \\
\hline Emblemariopsis signifer ${ }^{9}$ & Prohibited & $\mathrm{NE}$ & $\mathrm{LC}$ & - \\
\hline Epinephelus adscensionis ${ }^{18}$ & Prohibited & DD & $\mathrm{LC}$ & - \\
\hline Epinephelus itajara ${ }^{4 ; 20 ; 21}$ & Prohibited & $\mathrm{CR}$ & $\mathrm{CR}$ & - \\
\hline Epinephelus marginatus ${ }^{9}$ & Prohibited & VU & $\mathrm{EN}$ & - \\
\hline Epinephelus morio ${ }^{9}$ & Prohibited & VU & NT & - \\
\hline Equetus lanceolatus ${ }^{1 ; 4 ; 21}$ & Prohibited & $\mathrm{NE}$ & $\mathrm{LC}$ & - \\
\hline Fistularia tabacaria $9 ; 11 ; 18 ; 19$ & Allowed & $\mathrm{NE}$ & $\mathrm{LC}$ & - \\
\hline Gnatholepis thompsoni $i^{9}$ & Prohibited & $\mathrm{NE}$ & $\mathrm{LC}$ & - \\
\hline Gobiesox strumosus ${ }^{11 ; 18 ; 19}$ & Allowed & NE & $\mathrm{LC}$ & - \\
\hline Gramma brasiliensis ${ }^{2 ; 3 ; 4 ; 7 ; 8 ; 9 ; 15 ; 18 ; 20 ; 21 ; 23}$ & Prohibited & NT & $\mathrm{NE}$ & - \\
\hline Gymnachirus nudus ${ }^{11 ; 18 ; 19}$ & Allowed & NE & $\mathrm{LC}$ & - \\
\hline Gymnothorax funebris ${ }^{1 ; 6 ; 11 ; 18 ; 19 ; 22}$ & Allowed & DD & $\mathrm{LC}$ & - \\
\hline Gymnothorax miliaris $1 ; 4 ; 8 ; 11 ; 18 ; 19 ; 2 ; 24$ & Allowed & NE & $\mathrm{LC}$ & - \\
\hline Gymnothorax moringa $a^{9 ; 11 ; 18 ; 19 ; 24}$ & Allowed & DD & $\mathrm{LC}$ & - \\
\hline Gymnothorax ocellatus ${ }^{11 ; 18 ; 19}$ & Allowed & DD & $\mathrm{LC}$ & - \\
\hline Gymnothorax vicinus $s^{1 ; 9 ; 11 ; 18 ; 19}$ & Allowed & DD & $\mathrm{LC}$ & - \\
\hline Haemulon aurolineatum ${ }^{9}$ & Prohibited & $\mathrm{NE}$ & $\mathrm{LC}$ & - \\
\hline
\end{tabular}


Continued Table 1.

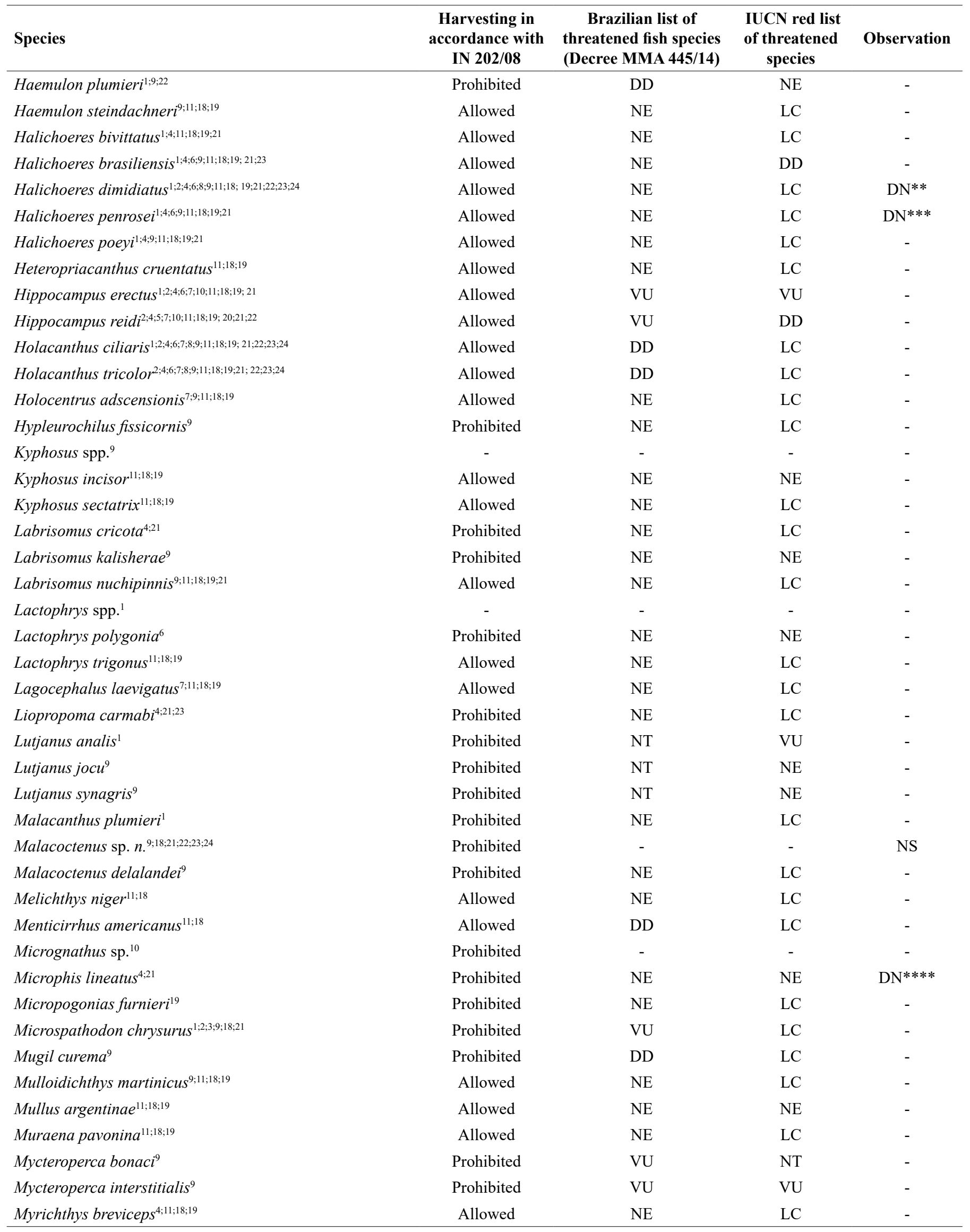


Gurjão, L.M. et al.

Continued Table 1.

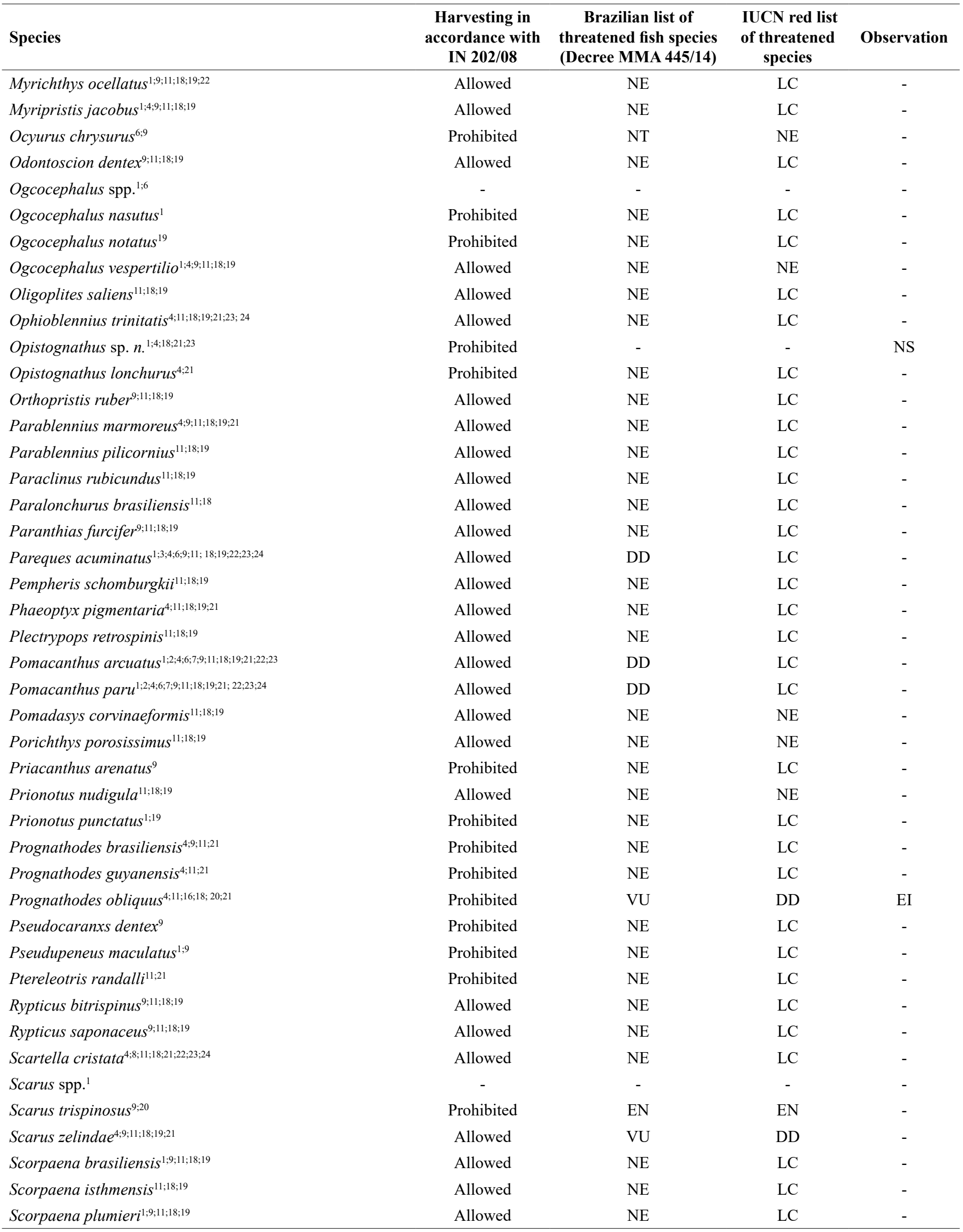


Brazilian species in marine aquarium trade

Continued Table 1.

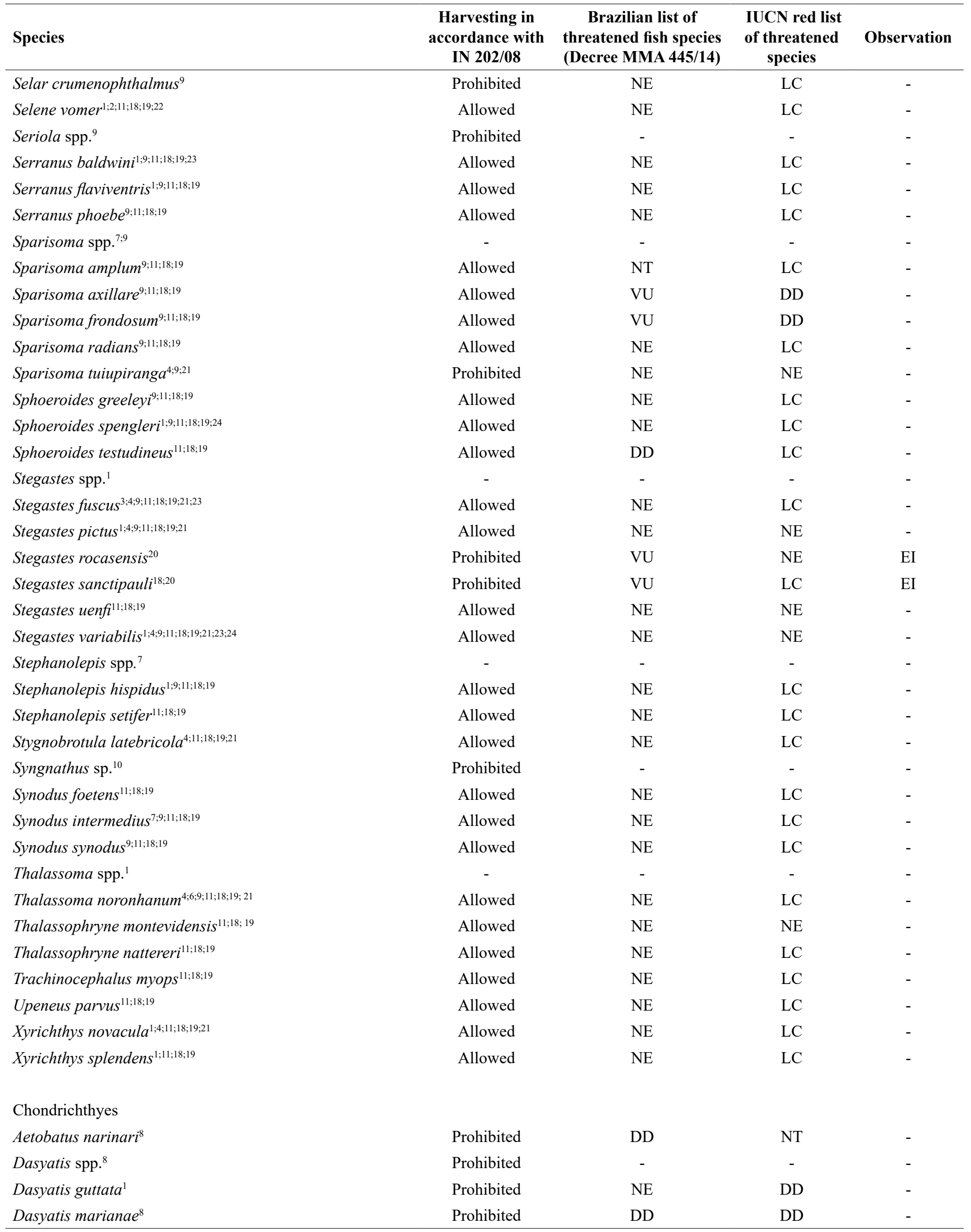


Continued Table 1.

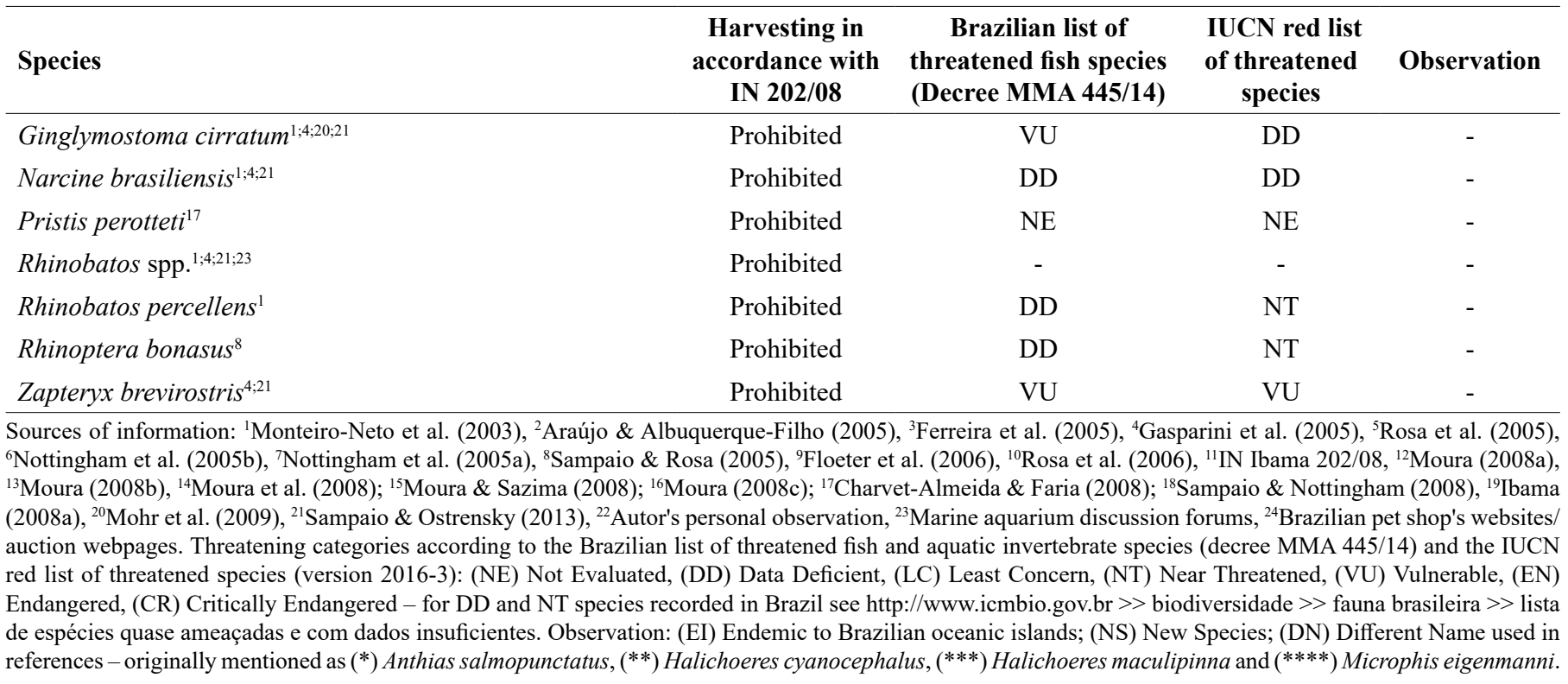

Table 2. Marine aquarium invertebrates traded in Brazil and their conservation status.

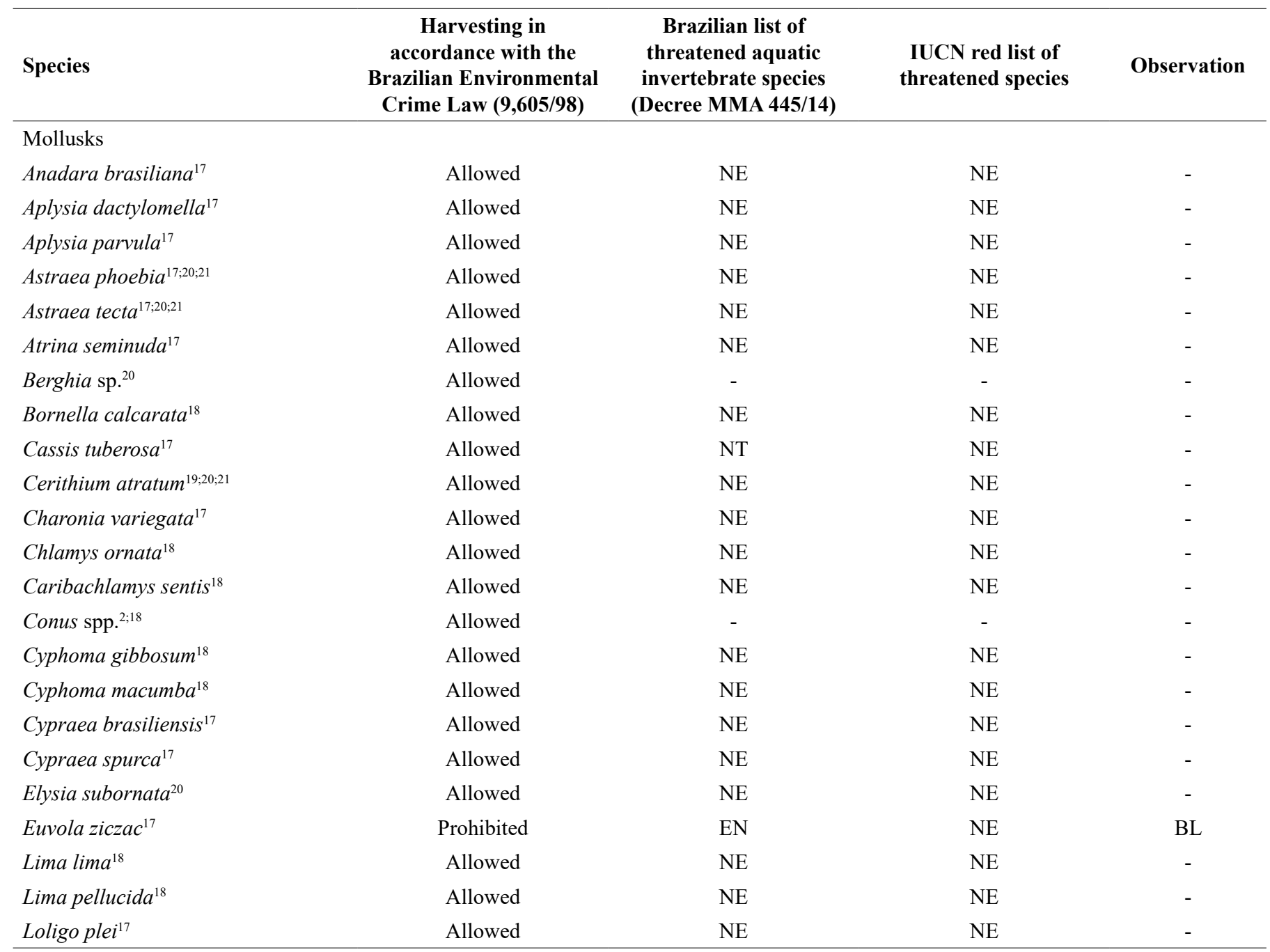


Continued Table 2.

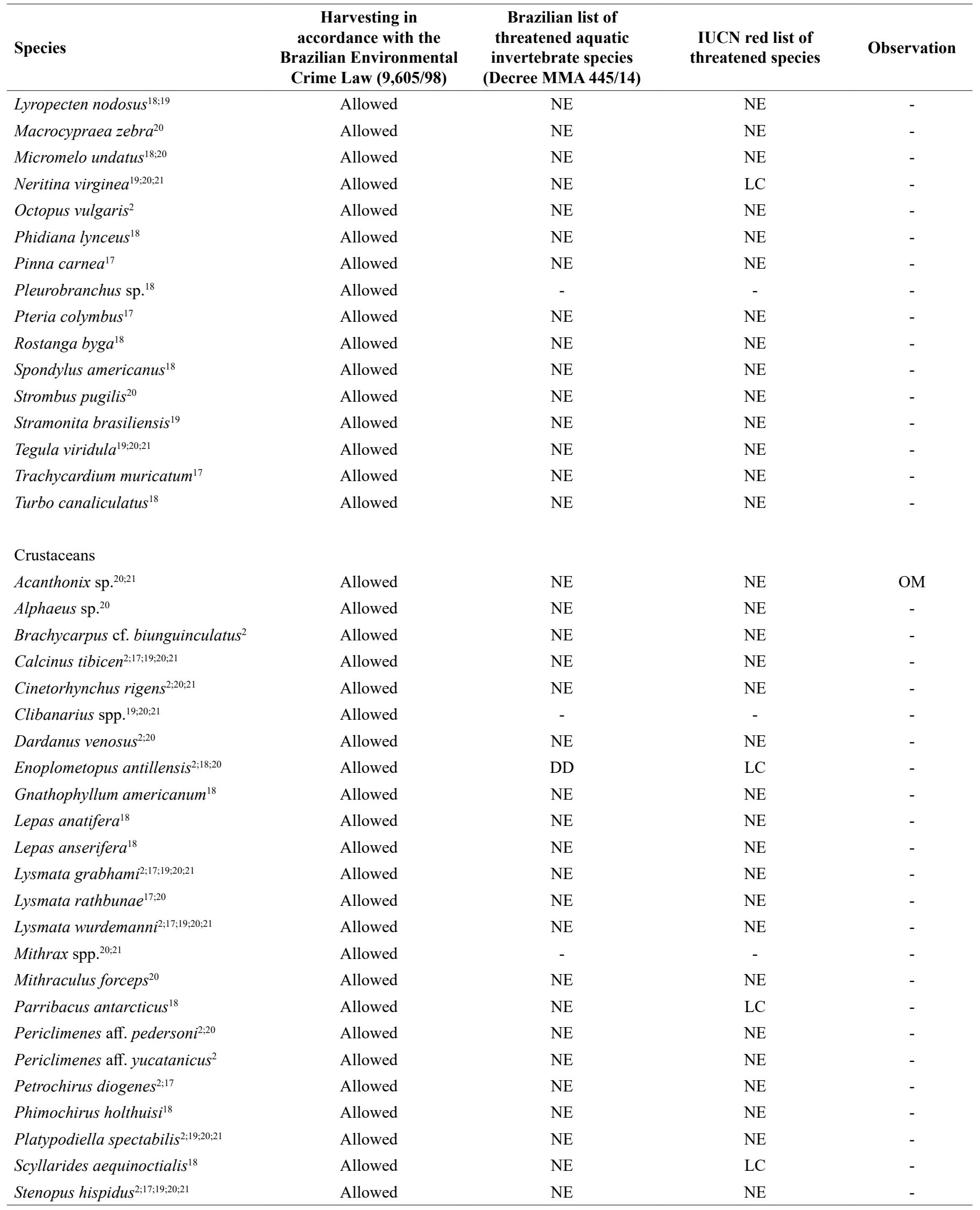


Gurjão, L.M. et al.

Continued Table 2.

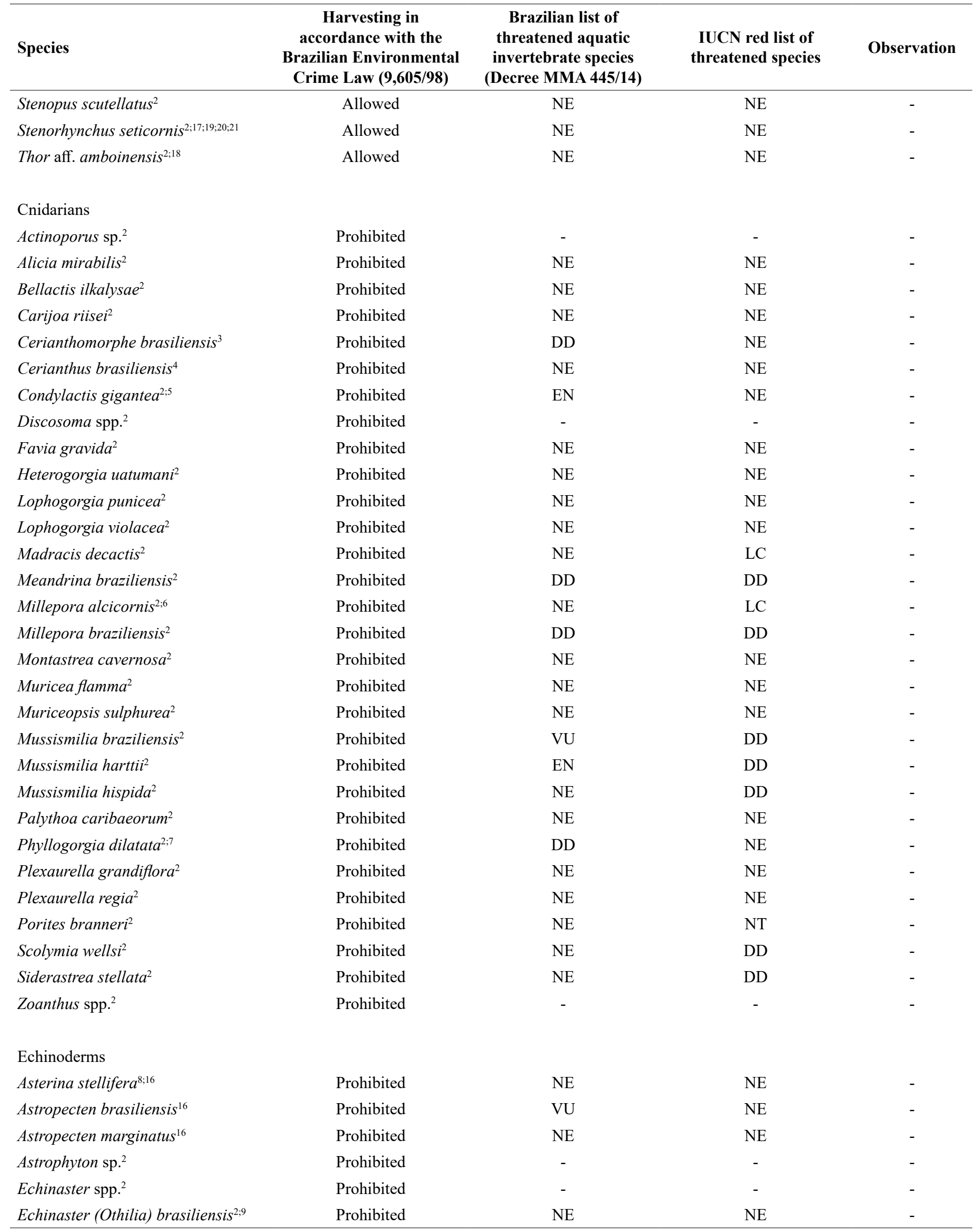


Continued Table 2.

\begin{tabular}{|c|c|c|c|c|}
\hline Species & $\begin{array}{c}\text { Harvesting in } \\
\text { accordance with the } \\
\text { Brazilian Environmental } \\
\text { Crime Law }(9,605 / 98)\end{array}$ & $\begin{array}{c}\text { Brazilian list of } \\
\text { threatened aquatic } \\
\text { invertebrate species } \\
\text { (Decree MMA 445/14) }\end{array}$ & $\begin{array}{l}\text { IUCN red list of } \\
\text { threatened species }\end{array}$ & Observation \\
\hline Echinaster (Othilia) guyanensis ${ }^{2}$ & Prohibited & $\mathrm{NE}$ & $\mathrm{NE}$ & - \\
\hline Echinometra lucunter ${ }^{20}$ & Prohibited & NE & NE & - \\
\hline Linckia guildingii ${ }^{2 ; 12 ; 19}$ & Prohibited & VU & $\mathrm{NE}$ & - \\
\hline Lytechinus variegatus ${ }^{20}$ & Prohibited & VU & NE & - \\
\hline Luidia clathrata $^{16}$ & Prohibited & NE & NE & - \\
\hline Luidia senegalensis ${ }^{16}$ & Prohibited & VU & NE & - \\
\hline Narcissia trigonaria $^{2 ; 13}$ & Prohibited & $\mathrm{NE}$ & NE & - \\
\hline \multicolumn{5}{|l|}{ Polychaetes } \\
\hline Eurythoe complanata $^{15}$ & Prohibited & $\mathrm{NE}$ & NE & - \\
\hline Spirobranchus spp. ${ }^{2}$ & Prohibited & $\mathrm{NE}$ & NE & - \\
\hline \multicolumn{5}{|l|}{ Ascidians } \\
\hline Botrylloides nigrum ${ }^{20}$ & Prohibited & NE & NE & IE \\
\hline Polycarpa insulsa ${ }^{20}$ & Prohibited & $\mathrm{NE}$ & NE & IE \\
\hline Tethya sp. ${ }^{1}$ & Prohibited & - & - & - \\
\hline
\end{tabular}

Source or information: ${ }^{1}$ Sampaio et al., (2004); ${ }^{2}$ Gasparini et al. (2005); ${ }^{3}$ Pires \& Castro (2008a); ${ }^{4}$ Pires \& Castro (2008b); ${ }^{5}$ Pires \& Castro (2008c); ${ }^{6}$ Pires \& Castro (2008d); ${ }^{7}$ Castro \& Pires (2008); ${ }^{8}$ Brites et al. (2008a); ${ }^{9}$ Ventura et al. (2008a); ${ }^{10}$ Ventura et al. (2008b); ${ }^{11}$ Ventura et al. (2008c); ${ }^{12}$ Brites et al. (2008b); ${ }^{13}$ Brites et al. (2008c); ${ }^{14}$ Brites et al. (2008d); ${ }^{15}$ Amaral et al. (2008); ${ }^{16}$ Amaral et al (2010); ${ }^{17}$ Authorization of exportation issued by Ibama; ${ }^{18}$ Authorization of exportation requested but not issued by Ibama; ${ }^{19}$ Author's personal observation; ${ }^{20}$ Marine aquarium discussion forums; ${ }^{21}$ Brazilian pet shop's websites/auction webpages; ${ }^{22} \mathrm{Hajdu}$ et al (2011). Threatening categories according to the Brazilian list of threatened fish and aquatic invertebrate species (decree MMA 445/14) and the IUCN red list of threatened species (version 2016-3): (NE) Not Evaluated, (DD) Data Deficient, (LC) Least Concern, (NT) Near Threatened, (VU) Vulnerable, (EN) Endangered. Observations: (BL) Although law 9,605/98 allows collection of mollusks, the species cannot be harvested since it is classified as EN in the Brazilian List of threatened fish and aquatic invertebrate species, (OM) Originally Misidentified as Xenocarcinus sp. or Macropodia longirostris, (IE) Incidental Exploitation attached to "liverocks".

Even though law 9,605/98 allows exploitation of mollusks and crustaceans (because they are defined as fishing resources), it prohibits the usage of species that figure in the Brazilian List of threatened fish and aquatic invertebrate species, as well as of those other invertebrates not defined as fishing resources (cnidarians, echinoderms, polychaetes, ascidians and sponges). Hence, exploitation of the bivalve Euvola ziczac (Linnaeus, 1758) is forbidden because it is classified as EN, according to decree MMA 445/14.
Table 2 also presents species that were misidentified in marine aquarium discussion forums and Brazilian pet shop's websites or auction webpages, besides organisms that were incidentally exploited attached to liverocks.

It was also recorded the use of seaweeds and saltwater macrophytes in marine tanks throughout the country (Table 3 ) and the great majority of species is neither cited in the Brazilian list of threatened flora species (decree MMA 443/14) nor in the IUCN red list of threatened species. The only exception is Halophila decipiens Ostenfeld, which is categorized as Least Concern (LC) solely in the IUCN red list. 
Gurjão, L.M. et al.

Table 3. Seaweeds and aquatic macrophytes used in marine aquarium trade in Brazil

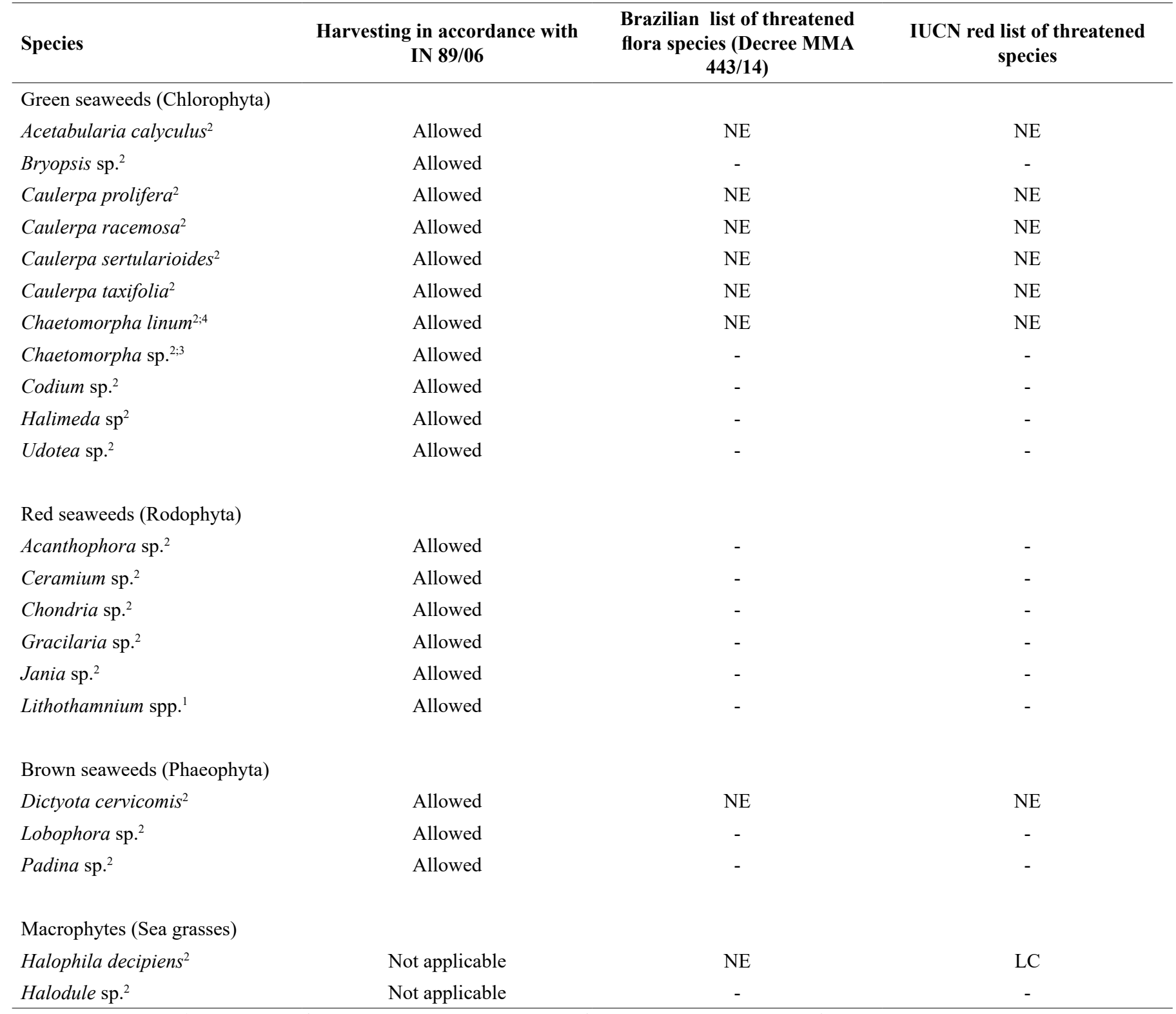

Source of information: ${ }^{1}$ Ibama (2008a); ${ }^{2}$ Marine aquarium discussion forums; ${ }^{3}$ Author's personal observation; ${ }^{4}$ Brazilian pet shop's websites/auction webpages. Threatening categories according to the Brazilian list of threatened flora species (decree MMA 443/15) and the IUCN red list of threatened species (version 2016-3): (NE) Not Evaluated, (LC) Least Concern.

\section{Discussion}

Web surveys have been successfully used to investigate aquarium trade worldwide (Kay \& Hoyle 2001; Walters et al. 2006; Keller \& Lodge 2007) and specifically in Brazil, this tool has been used to access the commerce of freshwater species (Magalhães \& Jacobi 2010; Magalhães et al 2017).

Many native species traded by the marine aquarium industry in Brazil figure in Brazilian lists of threatened species and, currently, it is much easier to compare these species with those categorized in the IUCN red list. Preceding Brazilian lists of threatened species (IN MMA 05/04 and IN MMA 52/05) had their own categories and classification criteria, but most recent Brazilian lists (decree MMA 443/14 and decree MMA 445/14) followed the IUCN red list patterns, which allow more reliable comparisons and avoid mismatches already detected - agreements regarding categories increase credibility of red lists, while desagreemends can either do the opposite or demonstrate that in particular cases a species may locally present a distinctive threatening degree compared to the general reality along its whole distribution (Bender et al. 2012). Bony fishes represent the great majority of the exploited species. Despite only 136 species can be legally commercialized according to IN Ibama 202/08, about 70 others are illegally traded in Brazil. This situation not only demonstrates a lack of more effective control and inspection by the Brazilian authorities (e.g. Ibama) but also indicates that many dealers and tank owners (i.e., aquarium hobbyists) simply either ignore or unknow the norms that regulate the exploitation of marine aquarium organisms. Such illegal trade is specially worrying because some organisms are included in the 
Brazilian list of threatened species under really threatening conservation statuses (e.g. EN or CR categories) or maybe worse, whose statuses are simply unknown (e.g. NE or DD categories).

Among many fish species, the barber goby Elacatinus figaro Sazima, Moura \& Rosa, 1997 (VU, in accordance with decree MMA 445/14) and the Brazilian basslet Gramma brasiliensis Sazima, Gasparini \& Moura, 1998 (whose harvesting was prohibited until December 2014, for being categorized as threatened with extinction by an older norm - IN MMA 05/04) were frequently cited by different sources of information investigated, indicating that, despite the prohibition of exploitation imposed by IN Ibama 202/08, both species are commonly found in ornamental trade.

This statement is corroborated through the seizure by Ibama of 18 E. figaro specimens, that were being illegally traded by means of the Brazilian postal service in 2010 (Gurjão et al. 2017), and another confiscation of E. figaro and G. brasiliensis specimens, at Guarulhos international airport, during the 2014 Fifa World Cup in Brazil. (http:// www.ibama.gov.br/publicadas/pagina-19-20). Another aspect that deserves special attention regarding the exploitation of the E. figaro is the potential negative ecological effect in reef areas, since it is a recognized cleaner species that plays an important role at cleaning stations and thus, in maintaining the functioning of the marine ecosystem (Sazima et al. 2000, Campos \& Sá-Oliveira 2011). Considering the Brazilian list of threatened species and the distribution of the fish traded, it must be highlighted that Choranthias salmopunctatus (Lubbock \& Edwards, 1981), Prognathodes obliquus (Lubbock \& Edwards, 1980), Stegastes rocasensis (Emery, 1972) and S. sanctipauli Lubbock \& Edwards, 1981 are endemic to Brazilian oceanic islands (e.g. Rocas Atoll and St Peter and St Paul's Archipelago - SPSPA) and, hence, their populations are more vulnerable to exploitation due to isolation (Mohr et al. 2009). Even considering the fragile aspects of these isolated populations and the prohibition of harvesting individuals at Brazilian oceanic islands by IN Ibama 202/08, almost all of them were already recorded as being captured for the aquarium industry - the only exception is C. salmopunctatus, which, despite never observed in the Brazilian ornamental market, is a desired species, specially by the millionaire Asian commerce, due to its unique characteristics (e.g. attractive color, rarity: low density/absolute number, and is the only species of the genus in Brazil) and extremely restricted geographic distribution (endemic to SPSPA: very limited horizontal and depth ranges) (Luiz-Júnior et al. 2007, Sampaio \& Nottingham 2008).

Some authors mention the aquarium trade of certain fish that could not be identified further than the genus level, but that comprise species listed in decree MMA 445/14: Micrognathus (M. erugatus - CR), Scarus (S. trispinosus - EN and S. zelindae-VU), Sparisoma (S. axillare-VU, $S$. frodosum - VU and S. rocha-VU), Stegastes (S. rocasensis - VU, $S$. sanctipauli - VU and S. trindadensis - VU), Dasyatis (D. centroura - CR and D. colarensis - VU) and Rhinobatos (R. horkelli - CR and $R$. lentiginosus - VU) (Monteiro et al. 2003, Gasparini et al. 2005, Nottingham et al. 2005a, Sampaio \& Rosa 2005, Rosa et al. 2006), thus, it is possible that other threatened species have been exploited by the Brazilian marine aquarium industry.

Other important threatened species are the longsnout (Hippocampus reidi Ginsburg, 1933) and lined (Hippocampus erectus Perry, 1810) seahorses. These species have received particular attention from the scientific community and Brazilian governmental authorities, who decided to keep them with the lowest exportation quota ( 250 specimens of each species/exporter/year). This is because populations pressed by aquarium harvesting activities had shown lower densities and smaller individuals (Ibama 2007, 2008a). However, the effectiveness of such measure is questionable since untrained and ill-intentioned dealers used to mislabel specimens of either $H$. erectus or $H$. reidi as they were Hippocampus kuda Bleeker, 1852 (Monteiro-Neto et al. 2003), while field surveys demonstrated that only $H$. reidi was actually exported, and the given quota could be doubled if $250 \mathrm{H}$. reidi were traded under the name of H. erectus (Rosa et al. 2011). Furthermore, there is still controversy about the distribution and taxonomy of Brazilian seahorses. Despite most authors state that $H$. reidi has a wider distribution along the Brazilian coast, while $H$. erectus is more restricted to southeastern and southern regions. However, evidences suggest that both species may have a continuous distribution along the Brazilian coast (Silveira 2011). Moreover, while $H$. reidi and $H$. erectus are the only valid names for the Brazilian seahorses (Fishbase 2017), a revision of the genus Hippocampus not only revealed that individuals identified in Brazil as H. erectus are morphologically and genetically similar to Hippocampus patagonicus Piacentino \& Luzzatto, 2004 (Silveira et al. 2014), but also indicated the existence of a highly population limited to northeastern Brazil, distinguishable from these two previously mentioned species (Ibama 2009, Rosa et al. 2011).

Taxonomic problems are also on traded labrid, opistognatid and labrosomid fish. After revalidation of some Brazilian wrasse species and reevaluation of their distribution (Rocha \& Rosa 2001, Rocha 2004), it is likely that specimens referred as Halichoeres radiatus (Linnaeus, 1758), Halichoeres cyanocephalus (Bloch, 1791) and Halichoeres maculipinna (Müller \& Troschel, 1848) in previous works were actually misidentified, and should be, in fact, the labrids Halichoeres brasiliensis (Bloch, 1791), Halichoeres dimidiatus (Agassiz, 1831) and Halichoeres penrosei Starks, 1913, respectively. Another possible mistake occurred for Opistognathus aurifrons (Jordan \& Thompson, 1905), which shall be in fact a new species of the same genus - Opistognathus sp. n. - (Sampaio \& Nottingham 2008) and a third taxonomic incongruity is related to the forbidden exploitation of a new labrosomid species - Malacoctenus sp. $\mathrm{n}$. (Floeter et al. 2003) -, which have been erroneously commercialized as a blenid, called 'red blenny'. Additionally, preceding articles also recorded the presence of Microphis eigenmanni in the Brazilian ornamental trade, which is a not valid synonym of Microphis lineatus (Kaup, 1856) (Fishbase 2017). Similarly, Canthigaster figueiredoi Moura \& Castro, 2002, used to be referred as Cantigaster rostrata (Bloch, 1786) in previous works (Sampaio \& Nottingham 2008). Therefore, some fish scientific names recorded here may be different from those reported on original papers, but are in accordance with the most recent synonyms used (Fishbase, 2017).

With regards to unthreatened species, angelfish have been systematically recorded among the most exploited species by the Brazilian marine aquarium industry (Nottingham et al. 2000, MonteiroNeto et al. 2003, Gasparini et al. 2005, Nottingham et al. 2005A, Feitosa et al. 2015) and despite the paucity of updated information about the exploitation of marine fish, the most recent official data available indicate that (Linnaeus, 1758), Holacanthus tricolor (Bloch, 1795), Pomacanthus paru (Bloch, 1787), Pomacanthus arcuatus (Linnaeus, 1758) and Centropyge aurantonotus Burgess, 1974, are still the most targeted species (Ibama 2008a). Another fact that corroborates this 
statement is the growing demand for pomacanthids in the international market throughout the years, which lead the Brazilian authorities to attribute differentiated exportation quotas to them - substantially higher than the ones given to the other species by means of the IN Ibama 202/08. Additionally, the illegal exploitation of rare specimens from isolated populations of $H$. ciliaris (e.g. wholly yellow, blue or white morphs and other unique color variants, endemic to SPSPA) (Feitoza et al. 2003, Luiz-Júnior 2003,), whose individual prices in the Japanese market can achieve up to US\$8.900,00, can decrease the genetic diversity (Gasparini et al. 2005) or even put these oddities in risk of extinction by means of an Anthropogenic Allee Effect (Courchamp et al. 2006).

None of the cartilaginous fish identified could be exploited according to IN Ibama 202/08, but such restriction is not entirely complied by the Brazilian aquarium industry. The clandestine harvest of these species is especially serious due to the fact that some sharks (Ginglymostoma cirratum (Bonnaterre, 1788), Zapteryx brevirostris (Müller \& Henle, 1841) and rays (Rhinobatus horkelii Müller \& Henle, 1841, Rhinobatus lentiginosus Garman, 1880, Dasyatis centroura (Mitchill, 1815) and Dasyatis colarensis Santos, Gomes \& Charvet-Almeida, 2004) are listed in decree MMA 445/14. Illegal collections of G. cirratum and rhinobatids for the ornamental trade are not uncommon (Monteiro-Neto et al. 2003, Gasparini et al. 2005, Mohr et al. 2009). On the other hand, the harvest of sawfish for the same purpose seems to be rarer, despite newborn individuals be ordered by the aquarium industry (Charvet-Almeida \& Faria, 2008). Regarding the trade of unthreatened sharks and rays, most species are sporadically harvested, with exception of Narcine brasiliensis (Olfers, 1831) and Rhinobatos percellens (Walbaum, 1792), whose captures involve a great number of newborn individuals and possibly are concentrated at a nursery site in Todos os Santos Bay, Bahia state, Northeastern Brazil (Sampaio \& Rosa 2005).

Concerning invertebrates, the exploitation of bivalves for marine aquarium purposes seems to be negligible in Brazil, when compared to other organisms. However, in 2005, one of the Brazilian most famous aquarium company requested Ibama's authorization to export these organisms. The company granted the demand for six species (Anadara brasiliana (Lamarck, 1819), Atrina seminuda (Lamarck, 1819), Euvola ziczac (Linnaeus, 1758), Pinna carnea Gmelin, 1791, Pteria colymbus (Roding, 1798) and Trachycardium muricatum (Linnaeus, 1758)) noting that exports of E. ziczac occurred prior to its inclusion as EN in the Brazilian list of threatened fish and aquatic invertebrate species in 2014-, but despite export of other species were not authorized for different reasons, they are still legally exploitable for the domestic market accorting to Federal Law 9,605/98.

Distinct groups of gastropods are explored by the Brazilian aquarium industry. The prosobranchs Cerithium atratum Born, 1778, Neritina virginea Linnaeus, 1758 and Tegula viridula (Gmelin, 1791) are widely commercialized as aquarium 'clean-up crew' or 'algae cleaners', due to their feeding habit of grazing on unwanted algae. Other prosobranchs are not frequently traded, but Brazilian aquarium dealers requested Ibama to give them authorization to export Cassis tuberosa (Linnaeus, 1758), Charonia variegata (Lamarck, 1816), Conus spp., Cyphoma gibbosum (Linnaeus, 1758), Cyphoma macumba Petuch, 1979, Cypraea brasiliensis Lorenz \& Hubert, 1993, Cypraea spurca Linnaeus, 1758 and Turbo canaliculatus Hermann, 1781. The harvest of Macrocypraea zebra (Linnaeus, 1758) and Strombus pugilis
Linnaeus, 1758 for marine tanks was mentioned at discussion forums and one of the authors observed a Stramonita brasiliensis Claremont \& Reid, 2011 specimen being sold at an aquarium pet shop, in Ceará state, Northeastern Brazil. However, since S. brasiliensis is a predatory sea snail and may feed on other mollusks inside marine tanks, it is possible that the species was mistakenly harvested and unintentionally being sold as a hermit crab carrying a mollusk empty shell.

Concerning opistobranchs, it shall be highlighted not only the maintenance of Elysia subornata (Verrill, 1901) individuals by aquarium hobbyists but also spawnings of the species inside tanks, discribed in discussion forums. In addintion, nudibranchs of the genus Berghia are wanted in marine aquariums to eradicate the undesirable sea anemone Aiptasia sp.

In spite of only two cephalopod species were recorded in the present inventory, it must be considered the possibility of exploitation of a third species, Octopus insularis Leite, Haimovici, Molina \& Warnke, 2008 - a recently described species from the $O$. vulgaris complex that might have been misidentified as the latter, due to their pattern of distribution along the Brazilian coast and other similarities (Leite et al. 2008).

At discussion forums, unidentified chitons (Polyplacophora) were also mentioned as being kept in marine aquariums either for controlling excessive growth of algae or for revolving sediments. In many cases, these organisms were reported to be collected incidentally, attached to fouled rocks placed into tanks.

None of the crustaceans recorded here figure in decree MMA445/14. The hermit crabs Calcinus tibicen (Herbst, 1791) and Clibanarius spp. are widely commercialized as members of the aforementioned 'clean up crew', while Dardanus venosus (H. Milne Edwards, 1848) is wanted for aesthetic reasons, since the species often has a sea anemone attached to its shell. Other uncommon hermit crabs are wanted by marine tank owners because of their unique size and beauty, e.g. the giant hermit crab Petrochirus diogenes (Linnaeus, 1758) and the red-strip hermit crab Phimochirus holthuisi (Provenzano, 1961), respectively.

Concerning other crabs, while Platypodiella spectabilis (Herbst, 1794) and Stenorhynchus seticornis (Herbst, 1788) are traded mainly for their color pattern and unique features, respectively - in spite of the latter also act as a cleaner of reef fish (Medeiros et al. 2011), the algae-eating crabs Mithrax spp. and Mithraculus forceps (MilneEdwards, 1875) (Olivotto et al. 2011), are desired to control the growth of unwanted bubble algae Valonia spp. inside tanks. It was recorded a probable taxonomic mistake in the identification of the decorator crab mentioned at discussion forums and sold online through pet shop websites. The species is mentioned as 'gorgonian spider-crab' or simply as 'gorgonian spider', under the scientific names Xenocarcinus sp. or Macropodia longirostris (Fabricius, 1775). However, as both genuses are not reported for Brazil (L. E. A. Bezerra pers. comm.) and the crab advertised is very cheap and, so, presumably not imported, it is more likely to be another majiid crustacean, the Brazilian decorator crab Acanthonyx sp.

Besides their beauty, shrimps Stenopus hispidus (Olivier, 1811) and Lysmata grabhami (Gordon, 1935) are known for removing ectoparasites from reef fish, while Lysmata wurdemanni (Gibbes, 1850) and Lysmata rathbunae Chace, 1970 are wanted to control population of Aiptasia sp. inside tanks. Gasparini et al (2005) also reported the trade of the gold coral banded shrimp, Stenopus scutellatus Rankin, 1898, but the occurrence of the species was not mentioned at any other source 
of information investigated here. The other shrimps Cinetorhynchus rigens (Gordon, 1936), Thor aff. amboinensis, Periclimenes aff. yucatanicus and Periclimenes aff. pedersoni are unusually sold in Brazilian market, despite their conspicuous body shape, color pattern, and behavioral characteristics, including the known cleaning activities of the latter (Floeter et al. 2007). The snapping shrimp Alphaeus sp., also infrequently traded, is kept specially to control flatworm populations inside marine tanks. Since there are 29 species of the genus Alphaeus in Brazil, including $A$. rudolphi spec. nov. - a new snapping shrimp of the Alpheus armatus species complex (Almeida \& Anker 2011), - it was not possible to determine whether one or more species of the genus is traded.

Despite unattractive featured for ornamental purposes, the potential exploitation of the barnacles Lepas anatifera Linnaeus, 1758 and Lepas anserifera Linnaeus, 1767, and the lobsters Gnathophyllum americanum Guérin-Méneville, 1855, Parribacus antarcticus (Lund, 1793) and Scyllarides aequinoctialis (Lund, 1793) was also recorded, since authorization from Ibama to export these organisms alive was also requested. The dwarf reef lobster, Enoplometopus antillensis Lütken, 1865 , also had its request of authorization for exportation denied by Ibama, but, differently from the other lobsters, this species is attractive to aquarium hobbyists at discussion forums due to its bright color and small size and, so, is still traded inside the country.

The recorded cnidarians belonged to distinct subgroups (sea anemones, octocorals, fire corals, besides other hard and soft corals) and among this wide variety of organisms, only three species are considered threatened in Brazil: Condylactis gigantea Weinland, 1860 (EN), Mussismilia braziliensis (Verrill 1868) (VU) and Mussismilia harttii (Verrill, 1868) (EN). Special attention shall be given to the illegal exploitation of $C$. gigantea, due to its intensive harvest by the ornamental industry in southeastern Brazil and its local extinction at Arraial do Cabo region, Rio de Janeiro state (Gasparini et al. 2005). Through discussion forums it was observed the illegal trade of sea whips, usually called 'monkey-tail gorgonian' and 'fox-tail gorgonian'. Despite forum members refer to them as members of the family Plexauridae, not only the precise identification of these two gorgonians is impossible based exclusively on common names, but also it is unknown whether or not they are recorded here, since this inventory mentions the plexaurid species Plexaurella grandiflora Verrill, 1912 and Plexaurella regia Barreira \& Castro, 1986.

The echinoderms listed were clearly dominated by sea stars, demonstrating the importance of a wide variety of species to the Brazilian aquarium trade. It is worth notice that some echinoderm species are threatened with extinction in Brazilian waters and authorities should give special attention to ban the harvest of two species: Linckia guildingii Gray, 1840, which have been traded illicitly through the Brazilian postal service (Gurjão et al. 2017) and Eucidaris tribuloides (Lamarck, 1816), which is constantly mentioned at discussion forums as being used in marine aquariums. Although sea cucumbers are not listed in the tables presented here, because it was not possible to identify the species traded, it was recorded the illegal selling of holothurians at discussion forums, under the common names 'giant sea cucumber', 'detritivorous sea cucumber' and 'burrowing sea cucumber'.

Differently from the other polychaetes identified here (Spirobranchus spp. and Eurythoe complanata (Pallas, 1766)), desired because of their beauty, Diopatra cuprea (Bosc, 1802) (categorized as VU in the Brazilian official list of threatened species) is indirectly used for ornamental purposes, as a source of food for some marine fish species (Steiner \& Amaral, 2008). In addition, exploitation of other unreported native polychaetes is likely to happen in Brazil, since the country supplies the UK ornamental market with such worms (Murray et al. 2012).

Tunicates were also recorded among organisms used in marine aquariums in Brazil. While Botrylloides nigrum Herdman, 1886, Styela plicata Lesuer, 1823 and possibly one unidentified didemnid seems to be unintentionally harvested adhered to live rocks taken from the wild and set into marine tanks, other species sold as 'black ascidian' and 'red ascidian' are deliberately traded by discussion forum members. As there was no photo of the black ascidian advertised, species could not be surely identified. However, due to its wide distribution throughout tropical waters, including Brazilian coast (Lotufo 2002), the possibility of the latter be the solitary Phallusia nigra Savigny, 1816 cannot be disregarded. Concerning the red ascidian, photos resembled Polycarpa insulsa (Sluiter, 1898). Although uncommon, previous studies had already recorded the presence of tunicates, as well as sponges, on other marine ornamental foreign markets (Wabnitz et al. 2003, Murray \& Watson 2014).

The four sponge species identified here, Aplysina fulva (Pallas, 1766), Axinyssa sp., Dragmacidon reticulatum (Ridley \& Dendy, 1886) and Tethya sp. are usually called 'yellow sponge', 'finger', 'red ball' and 'yellow ball', respectively (Sampaio et al. 2004). Discussion forums showed that sponges known as 'red ball' and 'yellow ball' are traded through the internet, however it was not possible to assure the species' identity based exclusively on common names. Additionally, the exploitation of a subespheric morphotype of D. reticulatum, called 'sponge-ball' and previously cited as Pseudaxinella reticulata (Ridley $\&$ Dendy, 1886), by the Brazilian aquarium industry have already been reported (Hajdu et al. 2011)

In Brazil, aquarium trade of seaweeds is extremely rare, since traditionally the co-habitation of corals and macroalgae is not wanted because seaweeds are avid competitors inside tanks, limiting coral growth. In most cases, macroalgae, e.g. Chaetomorpha spp., are kept solely in the aquarium's sump, aiming nitrogen and phosphorus removal. However, a few tank owners share their experience at discussion forums, keeping 'marine planted aquariums' rather than coral reef systems and, thus, seaweeds had been used associated to the sea grasses, e.g. Halophila decipiens Ostenfeld and Halodule sp. Due to the low relevance of 'marine planted aquariums' compared to 'mini reef systems' little attention has been paid to the exploitation of those resources, with exception of Ibama (2008a), which briefly mentioned the usage of macrophytes and Lithothamnium spp. in Brazilian aquarium trade.

The wide variety of native species inventoried in the present work demonstrates that Brazil is following the global trend of keeping diversified marine life in aquaria, which have caused increasing concern about the sustainability of reef ecosystems' exploitation (Wabnitz et al. 2003, LeGore et al. 2005, Calado 2006, LeGore et al 2008, Smith et al. 2010, Murray et al. 2012, Reynoso et al. 2012, Rhyne et al. 2012b).

The indiscriminate removal of pomacanthids (a true 'keystone guild') from reef ecosystems, for instance, might have serious negative reflexes (e.g. excessive sponge growth and less juveniles serving as 'cleaners') on community structure and these impacts caused to the reef might be greater than their abundance suggest (Gasparini et al. 2005). Similarly to other fish kept in aquaria, such as surgeonfish (mainly living 
plant consumers) and parrotfish (primarily detrital aggregates feeders), angelfish perform vital ecological roles in coral reef trophodynamics (e.g. controlling sponge and tunicate densities) (Hourigan et al. 1989, Hill 1998, Sazima et al. 1999, Andréa et al. 2007, Konow \& Bellwood 2011, Batista et al. 2012, Reis et al. 2012) and, thus, their overexploitation and inter-specific relationships had also being object of concern (Hill 1998, Comeros-Raynal et al. 2012). Nevertherless, the potential impact of fisheries targeting aquarium reef fish in Brazil is difficult to be evaluated, because little is known about the distribution of this type of fishing effort throughout the country and the actual level of threat to reef fish is hard to be assessed (Floeter et al. 2006).

Invertebrate grazers are also being collected at an increasingly rapid pace, mostly to control algal growth in home aquaria, but, as they play a corresponding role in the wild, their removal may strongly impact their native reefs (Rhyne et al. 2009). On healthy reefs, for instance, both the establishment and the survival of corals depend on high rates of herbivory to suppress macroalgae and reduce competition with cnidarians (Bonaldo \& Hay, 2014).

Another interspecific association, the cleaning activity, may be negatively affected by continuous harvesting of fish and shrimps, intensified by the high turnover in ornamental trade, since specialized cleaners generally have a short life in aquariums due to their distinctive feeding habits (Gasparini et al. 2005). Hence, since the influence of the species abundance on cleaning interactions is modulated by the trophic habits and social behavior of the interacting species, the removal of a single cleaner species from a reef will deeply affect the ecosystem functioning, as there seems to be little redundancy on this role when pairs of species are concerned (Floeter et al. 2007).

Not only Brazilian coral reefs but also estuaries (Nottingham et al., 2005b) and sponge reefs (Rocha et al., 2000; Andréa et al., 2007) may be affected by uncontrolled ornamental fisheries. Additionally, large endangered vertebrates can also be harmed by indiscriminate collection of invertebrates and depletion of banks of either macroalgae or macrophytes, e.g. marine turtles (Eretmochelys imbricata (Linnaeus, 1766) and Chelonia mydas (Linnaeus, 1758)), that feed on a wide variety of invertebrates or graze the substratum (Stampar et al., 2007; Goatley et al., 2012), and the Brazilian marine manatee, Trichechus manatus Linnaeus, 1758, whose diet is composed of seaweed and sea grass species identified here (Borges et al., 2008).

Hence, in the face of such concerning scenario, marine aquarium consumers have an important role requiring species from regulated fisheries and shipped in accordance with well-established guidelines (eco-labeled products) and Brazilian authorities must seek environment friendly measures (e.g. implementation of eco-fees to support research on marine ornamental fisheries and mariculture (Leal et al. 2015)).

Aquaculture initiatives must be incentivated, since they might considerably reduce collecting pressure over populations of targeted species (Calado et al. 2003, Pomeroy et al. 2006, Olivotto et al. 2011, Murray \& Watson 2014), specially because almost the totality of the native marine aquarium organisms exploited in Brazil are wild-caught and captive breeding of native marine ornamentals is restricted to a few species (e.g. Elacatinus figaro and Hippocampus reidi) (Meirelles 2008, Hora \& Joyeux 2009, Ibama 2009, Côrtes \& Tsuzuki 2010). However, captive breeding shall not entirely substitute wild-caught species, because many people depend on the harvesting of aquarium species to survive (Rhyne et al. 2014).
Another way of preventing or reducing overexploitation, would be through ecosystem-based management initiatives (Tissot et al. 2010, Rhyne et al. 2014), as the creation of new marine reserves and the adequate management of the existing ones, in order to promote recovery of stocks of heavily exploited species by the aquarium trade (Friedlander 2001, Tissot et al. 2004, Tissot et al. 2009, Stevenson \& Tissot 2013). Such initiatives, instead of preserving a particular species, aim not only the protection of the whole ecosystem but also assure the continuity of inter and intra-specific associations, including the safety of important spawning aggregation sites that are crucial for the survival of some aquarium traded species (Friedlander 2001, Gerhardinger et al. 2009, Comeros-Raynal et al. 2012, Feitosa et al. 2015).

In addition, IBAMA must intensity inspections driven to aquarium trade; IN Ibama 202/08 and decree MMA 445/14 must be reviewed by specialists to identify prohibited species; and educational campaigns explaining the dangers of overexploitation of marine life, involving aquarium stores, importers, wholesalers, retailers and aquarium hobbyists should be carried out.

\section{Acknowledgements}

The authors thank L. E. A. Bezerra (Labomar/UFC) for information regarding hermit and majiid crabs, two anonimous referees for valuable criticisms and the financial support received from PROAP/ CAPES-PPGCMT/LABOMAR-UFC to cover publishing costs.

\section{Autor Contributions}

Lívio Moreira de Gurjão: conceived the work, obtained and analyzed the data and wrote the manuscript;

Tito Monteiro da Cruz Lotufo: contributed to analysis and interpretation and also wrote the manuscript.

\section{Conflicts of interest}

The authors declare that they have no conflict of interest related to the publication of this manuscript.

\section{References}

ALMEIDA, A. O. \& ANKER, A. 2011 Alpheus rudolphi spec. nov., a new snapping shrimp from Northeastern Brazil (Crustacea: Decapoda: Alpheidae). Zool Meded 85:1-10.

AMARAL,A. C.Z., MIGOTTO, A. E., TURRA, A. \& SCHAEFFER-NOVELLI, Y. 2010. Araçá: biodiversity, impacts and threats. Biota Neotrop. 10(1):219264, http://dx.doi.org/10.1590/S1676-06032010000100022.

AMARAL, A. C. Z., RIZZO, A. E. \& STEINER, T. M. 2008. Eurythoe complanata (Pallas, 1778). In Livro vermelho da fauna brasileira ameaçada de extinção - Volume I (A. B. M. Machado, G. M. Drummond \& A. P. Paglia, eds.). Fundação Biodiversitas, Belo Horizonte, p. 280-281.

ANDRÉA, B. R., BATISTA, D., SAMPAIO, C. L. S. \& MURICY, G. 2007. Spongivory by juvenile angelfish (Pomacanthidae) in Salvador, Bahia State, Brazil. In Porifera Research: Biodiversity, innovation and sustainability (M. R. Custodio, G. Lôbo-Hajdu, E. Hajdu \& G. Muricy, eds.). Museu Nacional, Rio de Janeiro, p. 131-137.

ARAÚJO, M. E. \& ALBUQUERQUE-FILHO, A. C. 2005. Biologia das principais espécies de peixes ornamentais marinhos do Brasil: uma revisão bibliográfica e documental. Bol Tec Cient CEPENE 13(1):109-157. 
BATISTA, D., MURICY, G. R. S., ANDRÉA, B. R. \& VILLAÇA, R. C. 2012 High intraspecific variation in the diet of the french angelfish Pomacanthus paru in the south-western Atlantic. Braz J Oceanogr 60(3):449-454, http:// dx.doi.org/10.1590/S1679-87592012000300015.

BELLWOOD, D. R., HUGHES, T. P., FOLKE, C. \& NYSTRO, M. 2004. Confronting the coral reef crisis. Nature 429:827-833.

BENDER, M. G, FLOETER, S. R., FERREIRA, C. E. L. \& HANAZAKI N. 2012 Mismatches between global, national and local red lists and their consequences for Brazilian reef fish conservation. Endanger Species Res 18:247-254.

BONALDO R. M. \& HAY, M. E. 2014. Seaweed-Coral Interactions: Variance in Seaweed Allelopathy, Coral Susceptibility, and Potential Effects on Coral Resilience. PLoS ONE 9(1):e85786. https://doi.org/10.1371/journal. pone.0085786 (last access on 22/05/2017).

BORGES, J. C. G., ARAÚJO, P. G., ANZOLIN, D. G. \& MIRANDA, G. E. C. 2008. Identificação de itens alimentares constituintes da dieta dos peixes-boi marinhos (Trichechus manatus) na região Nordeste do Brasil. Biotemas 21(2):77-81.

BRITES, A. D., HADEL, V. F. \& TIAGO, C. G. 2008a. Asterina stellifera (Möbius, 1859). In Livro vermelho da fauna brasileira ameaçada de extinção - Volume I (A. B. M. Machado, G. M. Drummond \& A. P. Paglia, eds.). Fundação Biodiversitas, Belo Horizonte, p. 186-187.

BRITES, A. D., HADEL, V. F. \& TIAGO, C. G. 2008b. Linckia guildingii Gray, 1840. In Livro vermelho da fauna brasileira ameaçada de extinção - Volume I (A. B. M. Machado, G. M. Drummond \& A. P. Paglia, eds.). Fundação Biodiversitas, Belo Horizonte, p. 188-189.

BRITES, A. D., HADEL, V. F. \& TIAGO, C. G. 2008c. Narcissia trigonaria Sladen, 1889. In Livro vermelho da fauna brasileira ameaçada de extinção - Volume I (A. B. M. Machado, G. M. Drummond \& A. P. Paglia, eds.) Fundação Biodiversitas, Belo Horizonte, p. 189-190.

BRITES, A. D., HADEL, V. F. \& TIAGO, C. G. 2008d. Oreaster reticulatus (Linnaeus, 1758). In Livro vermelho da fauna brasileira ameaçada de extinção - Volume I (A. B. M. Machado, G. M. Drummond \& A. P. Paglia, eds.). Fundação Biodiversitas, Belo Horizonte, p. 191-192.

BRUCKNER, A. W. 2005. The importance of the marine ornamental reef fish trade in the wider Caribbean. Rev Biol Trop 53(1):127-138.

CALADO, R. 2006. Marine ornamental species from European waters: a valuable overlooked resource or a future threat for the conservation of marine ecosystems? Sci Mar 70(3):389-398.

CALADO, R., LIN, J., RHYNE, A. L., ARAÚJO, R. \& NARCISO, L. 2003. Marine ornamental decapods - popular, pricey, and poorly studied. J Crustacean Biol 23(4):963-973.

CAMPOS, C. E. C. \& SÁ-OLIVEIRA, J. C. 2011. Atividade de limpeza e clientes de Elacatinus figaro (Pisces: Gobiidae) nos recifes de coral dos Parrachos de Muriú, Nordeste do Brasil. Biota Neotrop 11(1):47-52, http://dx.doi. org $/ 10.1590 / \mathrm{S} 1676-06032011000100004$.

CASTRO, C. B. \& PIRES, D. O. 2008. Phyllogorgia dilatata (Esper, 1806) In Livro vermelho da fauna brasileira ameaçada de extinção - Volume I (A. B. M. Machado, G. M. Drummond \& A. P. Paglia, eds.). Fundação Biodiversitas, Belo Horizonte, p. 168-169.

CHARVET-ALMEIDA, P. \& FARIA, V. 2008. Pristis perotteti Müller \& Henle, 1841. In Livro vermelho da fauna brasileira ameaçada de extinção - Volume II (A. B. M. Machado, G. M. Drummond \& A. P. Paglia, eds.). Fundação Biodiversitas, Belo Horizonte, p. 33-34 [in Portuguese].

COMEROS-RAYNAL, M. T., CHOAT, J. H, POLIDORO, B. A., CLEMENTS, K. D., ABESAMIS, R., MATTHEW, T., CRAIG, M. T., LAZUARDI, M. E., MCILWAIN, J., MULJADI, A., MYERS, R. F., NAÑOLA-JUNIOR, C. L., PARDEDE, S., ROCHA, L. A., RUSSELL, B., SANCIANGCO, J. C., STOCKWELL, B., HARWELL, H. \& CARPENTE K. E. 2012. The Likelihood of Extinction of Iconic and Dominant Herbivores and Detritivores of Coral Reefs: The Parrotfishes and Surgeonfishes. PLoS ONE 7(7):e39825. https://doi.org/10.1371/journal.pone.0039825 (last access on 22/05/2017).

CÔRTES, G. F. \& TSUZUKI, M. Y. 2010. Efeito do tamanho do rotífero na sobrevivência e no crescimento de neon gobi Elacatinus figaro durante as fases iniciais de larvicultura. Bol Inst Pesca 36(3):205-212.
COURCHAMP, F., ANGULO, E., RIVALAN, P., HALL, R. J., SIGNORET, L., BULL, L. \& MEINARD, Y. 2006. Rarity value and species extinction: The anthropogenic Allee effect. PLoS Biol 4(12):e415. https://doi.org/10.1371/ journal.pbio.0040415 (last access on 22/05/2017).

FEITOSA, C. V., MARQUES, S., ARAÚJO, M. E. \& FERREIRA B. P. 2015. Reproduction of French angelfish Pomacanthus paru (Teleostei : Pomacanthidae) and implications for management of the ornamental fish trade in Brazil. Mar Freshwater Res 67(5):586-593, https://doi.org/10.1071/ MF14386.

FEITOZA, B. M., ROCHA, L. A., LUIZ-JUNIOR, O. J., FLOETER, S. R. \& GASPARINI, J. L. 2003. Reef fishes of St. Paul's Rocks: new records and notes on biology and zoogeography. Aqua, J Ichthyol Aquat Biol 7(2):61-82.

FERREIRA, C. E. L., GASPARINI, J. L., CARVALHO-FILHO, A. \& FLOETER S. R. 2005. A recently extinct parrotfish species from Brazil. Coral Reefs 24:128.

FISHBASE. http://www.fishbase.org/home.htm (last access in 23/05/2017).

FLOETER, S. R., GASPARINI, J. L., ROCHA, L. A., FERREIRA, C. E. L., RANGEL, C. A. \& FEITOZA B. M., 2003. Brazilian reef fish fauna: checklist and remarks. Available at: https://www.academia.edu/4807984/ Brazilian_reef_fish_fauna_checklist (last access on 22/05/2017).

FLOETER, S. R., HALPERN, B. S. \& FERREIRA, C. E. L. 2006. Effects of fishing and protection on Brazilian reef fishes. Biol Conserv 128:391-402.

FLOETER, S. R., VÁZQUEZ, D. P. \& GRUTTER A. S. 2007. The macroecology of marine cleaning mutualisms. J Anim Ecol 76:105-111.

FRIEDLANDER, A. M. 2001. Essential fish habitat and the effective design of marine reserves: Application for marine ornamental fishes. Aquarium Sciences and Conservation 3:135-150.

GASPARINI, J. L., FLOETER, S. R., FERREIRA, C. E. L. \& SAZIMA, I. 2005. Marine ornamental trade in Brazil. Biodivers Conserv 14:2883-2899.

GERHARDINGER, L. C., HOSTIM-SILVA, M., MEDEIROS, R. P., MATAREZI, J., BERTONCINI, A. A., FREITAS, M. O. \& FERREIRA B. P. 2009. Fishers' resource mapping and goliath grouper Epinephelus itajara (Serranidae) conservation in Brazil. Neotrop Ichthyol 7(1):93-102.

GOATLEY, C. H. R., HOEY, A. S. \& BELLWOOD, D. R. 2012. The role of turtles as coral reef macroherbivores. PLoS ONE 7(6):e39979. https://doi. org/10.1371/journal.pone.0039979 (last access on 22/05/2017).

GURJÃO, L. M., BARROS, G. M. L., LOPES, D. P., MACHADO, D. A. N. \& LOTUFO, T. M. C. 2017. Illegal trade of aquarium species through the Brazilian postal service in Ceará State. Mar Freshwater Res (Online Early). https://doi.org/10.1071/MF16257.

HAJDU, E., PEIXINHO, S. \& FERNANDEZ, J. C. C. 2011. Esponjas marinhas da Bahia: guia de campo e laboratório. Museu Nacional, Rio de Janeiro.

HILL, M. S. 1998. Spongivory on Caribbean reefs releases corals from competition with sponges. Oecologia 17(1):143-150.

HORA, M. S. C \& JOYEUX, J. C. 2009. Closing the reproductive cycle: growth of the seahorse Hippocampus reidi (Teleostei, Syngnathidae) from birth to adulthood under experimental conditions. Aquaculture 292:37-41.

HOURIGAN, T. F., STANTON, F. G., MOTTA, P. J., KELLEY, C. D. \& CARLSON, B. 1989. The feeding ecology of three species of Caribbean angelfishes (family Pomacanthidae). Environ Biol Fish 24(2):105-116.

IBAMA. 2007. Reunião nacional de ordenamento de peixes ornamentais marinhos e de águas continentais. Relatório COOPE: Ibama, Brasília.

IBAMA. 2008a. Diagnóstico geral das práticas de controle ligadas a exploração, captura, comercialização, exportação e uso de peixes para fins ornamentais e de aquariofilia. Relatório COOPE: Ibama, Brasília.

IBAMA. 2008b. Relatório da reunião nacional sobre o ordenamento do uso de invertebrados marinhos. Relatório COOPE: Ibama, Vitória.

IBAMA. 2009. Proposta de Plano de Gestão para o Uso Sustentável dos CavalosMarinhos do Brasil. CGFAP: Ibama, Brasília.

KAY, S. \& HOYLE, S. 2001. Mail order, the internet, and invasive aquatic weeds. J. Aquat. Plant Manag. 39: 88-91.

KELLER, R. P. \& LODGE, D. M. 2007. Species invasions from commerce in live aquatic organisms: problems and possible solutions. Bioscience 57 (5): $428-436$ 
KONOW, N. \& BELLWOOD, D. R. 2011. Evolution of high trophic diversity based on limited functional disparity in the feeding apparatus of marine angelfishes (f. Pomacanthidae). PLoS ONE 6(9):e24113. https://doi. org/10.1371/journal.pone.0024113 (last access on 22/05/2017).

LEAL, M. C., VAZ, M. C. M., PUGA, J., ROCHA, R. J. M., BROWN, C., ROSA, R. \& CALADO R. 2015. Marine ornamental fish imports in the European Union: an economic perspective. Fish Fish 17(2):459-468. http:// doi.org/10.1111/faf.12120

LEGORE, R. S., HARDIN, M. P., GARCIA-SAIS, J. R. \& BRICE J. R. 2008. Marine ornamental trade in Puerto Rico: rapid population assessment of primary target species. Rev Biol Trop 56(1):65-88.

LEGORE, R. S., HARDIN, M. P. \& TER-GHAZARYAN, D. 2005. Organization and operation of the marine ornamental fish and invertebrate export fishery in Puerto Rico. Rev Biol Trop 53(1):145-153.

LEITE, T. S., HAIMOVICI, M., MOLINA, W. \& WARNKE, K. 2008. Morphological and genetic description of Octopus insularis, a new cryptic species in the Octopus vulgaris complex (Cephalopoda: Octopodidae) from the tropical southwestern Atlantic. J Mollus Stud 74:63-74.

LOTUFO, T. M. C. 2002. Ascidiacea (Chordata: Tunicata) do litoral tropical brasileiro. Tese de doutorado, Universidade de São Paulo, São Paulo.

LUIZ-JÚNIOR, O. J. 2003. Colour Morphs in a Queen Angelfish Holacanthus ciliaris (Perciformes: Pomacanthidae) population of St. Paul's Rocks, NE Brazil. Tropical Fish Hobbyist 51(5):82-90.

LUIZ-JÚNIOR, O. J, JOYEUX, J. C. \& GASPARINI, J. L. 2007. Rediscovery of Anthias salmopunctatus Lubbock \& Edwards, 1981, with comments on its natural history and conservation. J Fish Biol 70: 1283-1286. http:// doi:10.1111/j.1095-8649.2007.01376.x.

MAGALHÃES, A. L. B. \& JACOBI, C. M. 2010. E-commerce of freshwater aquarium fishes: potential disseminator of exotic species in Brazil. Acta Scientiarum. Biological Sciences 32(3): 243-248.

MAGALHÃES, A. L. B., ORSI, M. L., PELICICE, F. M., AZEVEDO-SANTOS, V. M., VITULE, J. R. S., LIMA-JUNIOR, D. P. \& BRITO, M. F. G. 2017. Small size today, aquarium dumping tomorrow: sales of juvenile non-native large fish as an important threat in Brazil. Neotrop. Ichthyol. 15(4): e170033.

MEDEIROS, D. V., NUNES, J. A. C. C., REIS-FILHO, J. A. \& SAMPAIO, C. L. S. 2011. Yellowline arrow crab Stenorhynchus seticornis (Brachyura: Majidae) acting as a cleaner of reef fish, eastern Brazil. Mar Biodivers Rec 4:e68. https://doi.org/10.1017/S1755267211000637 (last access on 22/05/2017).

MEIRELLES, M. E., 2008. Viabilidade do cultivo do neon gobi, Elacatinus figaro. Dissertação de mestrado, Universidade Federal de Santa Catarina, Florianópolis.

MOHR, L. V., CASTRO, J. W. A., COSTA, P. M. S. \& ALVES, R. J. V. 2009. Ilhas oceânicas brasileiras: da pesquisa ao manejo - Volume II. Ministério do Meio Ambiente, Brasília.

MONTEIRO-NETO, C., CUNHA, F. E. A., NOTTINGHAM, M. C., ARAÚJO, M. E., ROSA, I. L. \& BARROS, G. M. L. 2003. Analysis of the marine ornamental fish trade at Ceará State, Northeast Brazil. Biodivers Conserv 12:1287-1295.

MOURA, R. L. 2008a. Bodianus insularis Gomon \& Lubbock, 1979. In Livro vermelho da fauna brasileira ameaçada de extinção - Volume II (A. B. M. Machado, G. M. Drummond \& A. P. Paglia, eds.). Fundação Biodiversitas, Belo Horizonte, p. 191-193.

MOURA, R. L. 2008B. Anthias salmopunctatus Lubbock \& Edwards, 1981. In Livro vermelho da fauna brasileira ameaçada de extinção - Volume II (A. B. M. Machado, G. M. Drummond \& A. P. Paglia, eds.). Fundação Biodiversitas, Belo Horizonte, p. 197-198.

MOURA, R. L. 2008C. Prognathodes obliquus (Lubbock \& Edwards, 1980). In Livro vermelho da fauna brasileira ameaçada de extinção - Volume II (A. B. M. Machado, G. M. Drummond \& A. P. Paglia, eds.). Fundação Biodiversitas, Belo Horizonte, p. 198-199.

MOURA, R. L. \& SAZIMA, I. 2008. Gramma brasiliensis Sazima, Gasparini \& Moura, 1998. In Livro vermelho da fauna brasileira ameaçada de extinção - Volume II (A. B. M. Machado, G. M. Drummond \& A. P. Paglia, eds.). Fundação Biodiversitas, Belo Horizonte, p. 190-191.
MOURA, R. L., SAZIMA, I. \& ROSA, R. S. 2008. Elacatinus figaro Sazima, Moura \& Rosa, 1997. In Livro vermelho da fauna brasileira ameaçada de extinção - Volume II (A. B. M. Machado, G. M. Drummond \& A. P. Paglia, eds.). Fundação Biodiversitas, Belo Horizonte, p. 188-189.

MURRAY, J. M. \& WATSON, G. J. 2014. A critical assessment of marine aquarist biodiversity data and commercial aquaculture: identifying gaps in culture initiatives to inform local fisheries managers. PLoS ONE 9(9):e105982. https://doi:10.1371/journal.pone.0105982 (last access on 23/05/2017).

MURRAY, J. M., WATSON, G. J., GIANGRANDE, A., LICCIANO, M. \& BENTLEY, M. G. 2012. Managing the marine aquarium trade: revealing the data gaps using ornamental polychaetes. PLoS ONE 7(1):e29543. https:// doi:10.1371/journal.pone.0029543 (last access on 23/05/2017).

NOTTINGHAM, M. C., CUNHA, F. E. A. \& MONTEIRO-NETO, C. 2000. Captura de peixes ornamentais marinhos no estado do ceará. Arq Cienc Mar 33:113-118.

NOTTINGHAM, M. C., BARROS, G. M. L., ARAÚJO, M. E., ROSA, I. M. L., FERREIRA, B. P. \& MELLO T. R. R. 2005a. O ordenamento da explotação de peixes ornamentais marinhos no Brasil. Bol Tec Cient CEPENE 13(1):75-107.

NOTTINGHAM, M. C., BARRETO, L. M., ARAÚJO, M. E., MONTEIRONETO, C., CUNHA, F. E. A., ROSA, I. M. L. \& ALENCAR, C. A. G. 2005b. A explotação de peixes ornamentais marinhos no estado do Ceará, Brasil: captura, manutenção nas empresas e exportação. Bol Tec Cient CEPENE 13(1):53-73.

OLIVOTTO, I., PLANAS, M., SIMÕES, N., HOLT, G. J., AVELLA, M. A. \& CALADO, R. 2011. Advances in breeding and rearing marine ornamentals. J World Aquacult Soc 42(2):135-166.

PIRES, D. O. \& CASTRO, C. B. 2008a Cerianthomorphe brasiliensis Carlgren, 1931. In Livro vermelho da fauna brasileira ameaçada de extinção - Volume I (A. B. M. Machado, G. M. Drummond \& A. P. Paglia, eds.). Fundação Biodiversitas, Belo Horizonte, p. 169-170.

PIRES, D. O. \& CASTRO, C. B. 2008b Cerianthus brasiliensis Mello-Leitão, 1919. In Livro vermelho da fauna brasileira ameaçada de extinção - Volume I (A. B. M. Machado, G. M. Drummond \& A. P. Paglia, eds.). Fundação Biodiversitas, Belo Horizonte, p. 171-172.

PIRES, D. O. \& CASTRO, C. B. 2008c Condylactis gigantea (Weinland, 1860). In Livro vermelho da fauna brasileira ameaçada de extinção - Volume I (A. B. M. Machado, G. M. Drummond \& A. P. Paglia, eds.). Fundação Biodiversitas, Belo Horizonte, p. 166-167.

PIRES, D. O. \& CASTRO, C. B. 2008d Millepora alcicornis Linnaeus, 1758. In Livro vermelho da fauna brasileira ameaçada de extinção - Volume I (A. B. M. Machado, G. M. Drummond \& A. P. Paglia, eds.). Fundação Biodiversitas, Belo Horizonte, p. 262-263.

POMEROY, R. S., PARKS, J. E. \& BALBOA, C. M. 2006. Farming the reef: is aquaculture a solution for reducing fishing pressure on coral reefs? Mar Policy 30:111-130.

REIS, F., MORAES, F., BATISTA, D., VILLAÇA, R., AGUIAR, A. \& MURIY, G. 2012. Diet of the queen angelfish Holacanthus ciliaris (Pomacanthidae) in São Pedro e São Paulo Archipelago, Brazil. J Mar Biol Assoc UK 93(2S):453-460. https://doi:10.1017/S0025315412001099.

REYNOSO, F. L., CASTAÑEDA-CHÁVEZ, M., ZAMORA-CASTRO, J. E., HERNÁNDEZ-ZÁRATE, G., RAMÍREZ-BARRAGÁN, M. A. \& SOLÍSMORÁN, E. 2012. La acuariofilia de especies ornamentales marinas: un mercado de retos y oportunidades. Lat Am J Aquat Res 40:12-21. http:// dx.doi.org/10.4067/S0718-560X2012000100002.

RHYNE, A., ROTJAN, R., BRUCKNER, A. \& TLUSTY, M. 2009. Crawling to collapse: ecologically unsound ornamental invertebrate fisheries. PLoS ONE 4(12):e8413. https://doi:10.1371/journal.pone.0008413 (last access on $23 / 05 / 2017)$.

RHYNE, A. L., TLUSTY, M. F. \& KAUFMAN, L. 2012a. Long-term trends of coral imports into the United States indicate future opportunities for ecosystem and societal benefits. Conserv Lett 5:478-485. https://doi:10.1111/ j.1755-263X.2012.00265.x. 
RHYNE, A. L., TLUSTY, M. F., SCHOFIELD, P. J., KAUFMAN, L., MORRISJUNIOR, J. A., BRUCKNER, A. W. 2012b. Revealing the appetite of the marine aquarium fish trade: the volume and biodiversity of fish imported into the United States. PLoS ONE 7 (5): e35808. https://doi:10.1371/journal. pone.0035808 (last access on 23/05/2017).

RHYNE, A. L., TLUSTY, M. F. \& KAUFMAN, L. 2014. Is sustainable exploitation of coral reefs possible? A view from the standpoint of the marine aquarium trade. Curr Opin Env Sust 7:101-107.

ROCHA, L. A., ROSA, I. L. \& FEITOZA, B. M., 2000. Sponge-dwelling fishes of Northeastern Brazil. Environ Biol Fish 59:453-458.

ROCHA, L. A., 2004. Mitochondrial DNA and color pattern variation in three western Atlantic Halichoeres (Labridae), with the revalidation of two species. Copeia 4:770-782.

ROCHA L. A. \& ROSA R. S. 2001. Halichoeres brasiliensis (Bloch, 1791), a valid wrasse species (Teleostei: Labridae) from Brazil, with notes on the Caribbean species Halichoeres radiatus (Linnaeus, 1758). Aqua, JIchthyol Aquat Biol 4:161-166.

ROSA, I. M. L., BARROS, A. T., XAVIER, J. H. A. \& CORTEZ, C. S. 2005. Dados populacionais de cavalos-marinhos Hippocampus reidi Ginsburg, 1933 (Teleostei: Syngnathidade) capturados para fins de aquarismo no nordeste do Brasil. Bol Tec Cient CEPENE 13 (1): 25-38.

ROSA, I. M. L., SAMPAIO, C. L. S. \& BARROS, A. T. 2006. Collaborative monitoring of the ornamental trade of seahorses and pipefishes (Teleostei: Syngnathidae) in Brazil: Bahia State as a case study. Neotrop Ichthyol $4(2): 247-252$.

ROSA, I. L., OLIVEIRA, T. P. R., OSÓRIO, F. M., MORAES, L. E., CASTRO, A. L. C., BARROS, G. M. L. \& ALVES, R. R. N. 2011. Fisheries and trade of seahorses in Brazil: historical perspective, current trends, and future directions. Biodivers Conserv 20(9):1951-1971.

SAMPAIO, C. L. S., LIMA, M. L. \& PEIXINHO, S. 2004. Esponjas marinhas capturadas com fins ornamentais em Salvador, Bahia. In XXV Congresso Brasileiro de Zoologia, Brasília, p. 373.

SAMPAIO, C. L. S. \& ROSA, I. M. L. 2005. A coleta de peixes ornamentais marinhos na Bahia, Brasil: técnicas utiizadas e implicações à conservação. Bol Tec Cient CEPENE 13(1):39-51.

SAMPAIO, C. L. S. \& NOTTINGHAM, M. C. 2008. Guia de identificação de peixes ornamentais brasileiros - Espécies marinhas - Volume I. Ministério do Meio Ambiente, Brasília.

SAMPAIO, F. D. F. \& OSTRENSKY, A. 2013. Brazilian environmental legislation as tool to conserve marine ornamental fish. Mar Policy 42:280-285.

SAZIMA, I., MOURA, R. L. \& SAZIMA, C. 1999. Cleaning activity of juvenile angelfish, Pomacanthus paru, on the reefs of the Abrolhos Archipelago, Western South Atlantic. Environ Biol Fish 56(4):399-407.

SAZIMA, I., SAZIMA, C., FRANCINI-FILHO, R. B. \& Moura, R. L. 2000 Daily cleaning activity and diversity of clients of the barber goby, Elacatinus figaro, on rocky reefs in Southeastern Brazil. Environ Biol Fish 59:69-77.

SILVEIRA R. B. 2011. Registros de cavalos-marinhos (Syngnathidae: Hippocampus) ao longo da costa brasileira. Oecologia Australis 15(2):316325.
SILVEIRA R. B., SICCHA-RAMIREZ, R., SILVA, J. R. S. \& OLIVEIRA, C. 2014. Morphological and molecular evidence for the occurrence of three Hippocampus species (Teleostei: Syngnathidae) in Brazil. Zootaxa 3861(4):317-332. http://dx.doi.org/10.11646/zootaxa.3861.4.2

SMITH, K. A., NEWMAN, S. J. \& CLIFF, G. M. 2010. Marine Aquarium Fish Managed Fishery. ESD Report Series 8 - Department of Fisheries: The Government of Western Australia, Perth.

STAMPAR, S. N., SILVA, P. F. \& LUIZ-JÚNIOR, O. J. 2007. Predation on the Zoanthid Palythoa caribaeorum (Anthozoa, Cnidaria) by a hawksbill turtle (Eretmochelys imbricata) in Southeastern Brazil. Marine Turtle Newsletter 117:3-5.

STEINER, T. M. \& AMARAL, A. C. Z., 2008. Diopatra cuprea Bosc, 1802. In Livro vermelho da fauna brasileira ameaçada de extinção - Volume I (A. B. M. Machado, G. M. Drummond \& A. P. Paglia, eds.). Fundação Biodiversitas, Belo Horizonte, p. 283-285.

STEVENSON, T. C., TISSOT, B. N. \& WALSH, W. J. 2013. Socioeconomic consequences of fishing displacement from marine protected areas in Hawaii. Biol Conserv 160:50-58. https://doi.org/10.1016/j.biocon.2012.11.031

TISSOT, B. N., BEST, B. A, BORNEMAN, E., BRUCKNER, A. W., COOPER, C. H., D'AGNES, H., FITZGERALD, T. P., LELAND, A., LIEBERMANG, S., AMOS, A. M., SUMAILA, R., TELECKY, T. M., MCGILVRAY, F., PLANKIS, B. J., RHYNE, A., ROBERTS, G. G., STARKHOUSE, B. \& STEVENSON, T. C. 2010. How US ocean policy and market power can reform the coral reef wildlife trade. Mar Policy 34:1385-1388. https://doi. org/10.1016/j.marpol.2010.06.002.

TISSOT, B. N., WALSH, W. J. \& HALLACHER, L. E. 2004. Evaluating effectiveness of a marine protected area network in West Hawai' $i$ to increase productivity of an aquarium fishery. Pac Sci 58(2):175-188.

TISSOT, B. N., WALSH, W. J. \& HIXON, M. A. 2009. Hawaiian islands marine ecosystem case study: ecosystem and community-based management in Hawaii'. Coast Manage 37(3):255-273.

VENTURA, C. R. R., BARCELLOS, C. F. \& SOUZA, I. V. 2008a. Echinaster (Othilia) brasiliensis Müller \& Troschel, 1842. In Livro vermelho da fauna brasileira ameaçada de extinção - Volume I (A. B. M. Machado, G. M. Drummond \& A. P. Paglia, eds.). Fundação Biodiversitas, Belo Horizonte, p. $182-183$.

VENTURA, C. R. R., BARCELLOS, C. F. \& SOUZA, I. V. 2008b. Echinaster (Othilia) echinophorus Lamarck, 1816. In Livro vermelho da fauna brasileira ameaçada de extinção - Volume I (A. B. M. Machado, G. M. Drummond \& A. P. Paglia, eds.). Fundação Biodiversitas, Belo Horizonte, p. 183-184.

VENTURA, C. R. R., BARCELLOS, C. F. \& Souza, I. V. 2008c. Eucidaris tribuloides Lamarck, 1816. In Livro vermelho da fauna brasileira ameaçada de extinção - Volume I (A. B. M. Machado, G. M. Drummond \& A. P. Paglia, eds.). Fundação Biodiversitas, Belo Horizonte, p. 251-252.

WABNITZ, C., TAYLOR, M., GREEN, E. \& RAZAK, T. 2003. From Ocean to Aquarium. UNEP-WCMC, Cambridge.

WALTERS, L. J., BROWN, K. R., STAM, W. T. \& OLSEN, J. L. 2006. E-commerce and Caulerpa: unregulated dispersal of invasive species. Front. Ecol. Environ. 4(2): 75-79.

WOOD, E. 2001. Collection of coral reef fish for aquaria: global trade, conservation issues and management strategies. Marine Conservation Society, Ross-on-Wye. 